\title{
TRANSFORMAÇÕES SOCIAIS E (RE)TERRITORIALIZAÇÃO WARAO NO BRASIL: A TRAJETÓRIA DE UMA FAMÍLIA FRENTE À PANDEMIA DE COVID-19 1
}

\author{
CLÉMENTINE MARÉCHAL ${ }^{2}$ \\ UFRGS, BRASIL \\ https://orcid.org/0000-0002-5676-3985
}

\begin{abstract}
AUGUSTO LEAL DE BRITTO VELHO ${ }^{3}$
UFRGS, BRASIL

https://orcid.org/0000-0002-3438-2276
\end{abstract}

MILENA WEBER RODRIGUES ${ }^{4}$

UFRGS, BRASIL

https://orcid.org/0000-0002-3060-3481

PIETRO BUENO 5

UFRGS, BRASIL

https://orcid.org/0000-0002-4015-1001

\begin{abstract}
RESUMO: Este artigo busca, a partir de um exemplo etnográfico especifico, tornar visivel a complexidade e a pluralidade das dimensões que permeiam a situação migratória vivida pelos coletivos warao no Brasil. Escrito a 8 mãos em plena pandemia e atravessado pelos impactos do isolamento social, este trabalho se inscreve em uma pesquisa mais ampla de antropologia social $e$ histórica. Destacamos 3 elementos centrais e entrelaçados que parecem atravessar a (re)organização social, econômica, política e espiritual da família de Florencia e Rodolfo no seu deslocamento para o Brasil. Primeiramente, a busca por najoro (comida), que se constitui como um dos principais argumentos dos Warao para atravessar a fronteira com o Brasil, considerado um lugar de abundância em relação à escassez na Venezuela. Em segundo lugar, as doenças, que para os Warao têm sua origem na atuação dos hebu ou hebu zabana, formam parte do cotidiano destes coletivos no Brasil. O último elemento diz respeito às estruturas materiais de sobrevivência construidas pelos Warao ao longo das suas caminhadas pela Venezuela e pelo Brasil.
\end{abstract}

PALAVRAS-CHAVE: Warao, Migração, Covid-19, Comensalidade, Cosmologia, Trabalho.

\footnotetext{
1 Este trabalho foi desenvolvido no marco do projeto de pesquisa intitulado: "Processos de Territorialização, Estruturas de Subsistência e Relações Interétnicas na Imigração Warao no Brasil: Etnologia e história de um grupo étnico em transformação", coordenado pelo professor Pablo Quintero e vinculado ao Núcleo de Antropologia das Sociedades Indígenas e Tradicionais do Programa de Pós-Graduação em Antropologia Social da Universidade Federal do Rio Grande do Sul (NIT/PPGAS/UFRGS).

2 Doutoranda em antropologia social e integrante do Núcleo de Antropologia das Sociedades Indígenas e Tradicionais do Programa de Pós-Graduação em Antropologia Social (NIT/PPGAS/UFRGS). E-mail: clementine.marechal08@gmail.com

${ }^{3}$ Graduando em Ciências Sociais (UFRGS) e integrante do Núcleo de Antropologia das Sociedades Indígenas e Tradicionais (NIT/PPGAS/UFRGS). E-mail: britto.velho@ufrgs.br

${ }^{4}$ Graduanda em Ciências Sociais (UFRGS) e integrante do Núcleo de Antropologia das Sociedades Indígenas e Tradicionais (NIT/PPGAS/UFRGS). E-mail: milena.wber@gmail.com

${ }^{5}$ Graduando em Ciências Sociais (UFRGS e integrante do Núcleo de Antropologia das Sociedades Indígenas e Tradicionais (NIT/PPGAS/UFRGS E-mail: pietro.bueno@ufrgs.br 
Espaço Ameríndio

ABSTRACT: This article seeks, based on a specific ethnographic example, to make visible the complexity and plurality of dimensions that permeate the migratory situation experienced by Warao collectives in Brazil. Eight-handedly written amidst a pandemic and crossed by the impacts of social isolation, this work is part of an initial research on social and historical anthropology. We highlight 3 central and intertwined elements, which seem to cross the social, economic and spiritual (re)organization of Florencia and Rodolfo's family along their displacement to Brazil. First, the search for najoro (food), which constitutes one of the main Warao's arguments for crossing the border to Brazil, considered a place of abundance in comparison to the scarcity in Venezuela. Secondly, diseases, which for the Warao have their origin in the activities of the hebu or hebu zabana, and are part of the daily life of these collectives in Brazil. The last element concerns the material survival structures built by the Warao during their circuits through Venezuela and Brazil.

KEYWORDS: Warao, Migration, Covid-19, Commensality, Cosmology, Labour. 


\section{Introdução}

A crise sanitária no Brasil provocada pela Covid-19 fez grande número de vítimas dentro de grupos vulneráveis e populações de baixa renda. São esses grupos que, inseridos na matriz de dominação colonial/moderna/capitalista ${ }^{6}$, se encontram à mercê dos interesses do capital e do Estado brasileiro. Precisam sair para trabalhar e conquistar diariamente meios de reproduzir a vida entre os seus, expondo-se ao vírus, muitas vezes sem que sejam garantidas as condições sanitárias básicas nos locais de trabalho. É importante evidenciar que dentro desse contexto, em 19 de setembro de 2020, o Brasil já contava com mais de 32.615 indígenas infectados, e 818 indígenas mortos pela Covid-19, tendo o vírus se disseminando entre $158 \mathrm{povos}^{7}$, dentre eles, os warao. Segundo dados coletados nessa mesma data na página da Articulação dos Povos Indígenas do Brasil (APIB), estão registrados ao todo 7 óbitos de indígenas warao relacionados à Covid- $19^{8}$, distribuídos nas regiões Norte e Nordeste, tendo o último óbito sido registrado em 14 de julho de $2020^{\circ}$. Contudo, devido à dificuldade em mapear todos os núcleos familiares warao no Brasil, é bastante provável que o número de atingidos e defuntos em decorrência da Covid-19 seja maior.

\section{Da situação etnográfica}

Conhecemos Florencia e Rodolfo um pouco antes da pandemia do coronavírus se expandir pelo Brasil. O casal, acompanhado por sua neta de 4 anos, deixou sua família em Cuiabá, e de lá veio para Porto Alegre, onde alugava um quarto de hotel por $\mathrm{R} \$ 60$ a diária, perto da rodoviária da cidade. Para pagar o alojamento e a comida, Florencia pedia dinheiro nos semáforos com a ajuda de uma placa que trouxera de sua passagem por Manaus, onde podia-se ler em português: "Sou indígena de Venezuela, preciso de dinheiro para comer". Mais tarde, Florencia relatou que para "pedir" - ine naroya burata ebú quitane, literalmente, "eu saio para pedir moeda" - costuma cantar no seu idioma nativo, uma prática comum que acompanha as tarefas diárias das mulheres warao, como a fabricação de artesanato ou a preparação da comida. As letras das canções de Florencia,

\footnotetext{
${ }^{6}$ A matriz de dominação colonial faz referência ao conceito de colonialidade do poder, desenhado pelo sociólogo peruano Aníbal Quijano. A colonialidade refere-se à matriz estrutural de poder específica da modernidade, originada a partir da colonização da América no século XVI e consequentemente à hegemonia global europeia. Compõe-se historicamente a partir da associação entre um novo sistema de dominação baseado em uma trama de relações sociais inter-subjetivas que classifica hierarquicamente a população mundial, e um sistema de exploração que consiste na articulação de todas as formas de expropriação do trabalho em uma única estrutura de produção mercantil hegemonizada pelo capitalismo. Nesse sentido, a colonialidade é um dos elementos constitutivos do padrão de poder capitalista. A associação estrutural entre esses dois sistemas articula as classificações sociais baseadas nas ideias de raça, gênero e classe como novas identidades geoculturais globais com o novo sistema mundial de controle do trabalho (QUINTERO, 2014).

${ }^{7}$ Fonte : < https://covid19.socioambiental.org/>. Acesso em: 19/09/2020.

${ }^{8}$ Em comunicação pessoal com Marlise Rosa e Pablo Quintero soubemos que, em setembro de 2020, os óbitos totais de pessoas Warao no Brasil alcançaram 101 pessoas, muitas delas crianças.

${ }^{9}$ Fonte: $<$ http://emergenciaindigena.apib.info/dados_covid19/>. Acesso em: 19/09/2020. 
entretanto, são inventadas e reelaboradas no fio das suas andanças pelo Brasil $^{10}$.

Surpreendida pela pandemia da Covid-19 e as recomendações de isolamento social, Florencia viu sua renda diária cair consideravelmente. Dessa maneira, longe de preocupações de pesquisas e coleta de dados, o estabelecimento da nossa relação com a família warao se inscreveu nos marcos de uma "participação-observante" (ALBERT, 2014), pois nosso primeiro e principal objetivo era ajudar essa família a sobreviver à crise de Covid-19 em Porto Alegre. Como primeira iniciativa, realizamos um financiamento coletivo no intuito de juntar dinheiro para cobrir os gastos de aluguel e comida de tais indígenas, além de dar visibilidade para uma situação inédita: a família de Florencia e Rodolfo foi a primeira a chegar tão ao sul do Brasil. Nessa perspectiva, buscamos também um apoio mais estrutural com instituições e órgãos competentes nas esferas dos direitos humanos e da saúde indígena. Tínhamos dois objetivos: 1) ou encontrar um alojamento para a família de Florencia, um lugar onde ela poderia cozinhar longe de preocupações e dificuldades com os outros moradores da pensão. Em várias ocasiões Florencia nos relatou por telefone que o frango que a família deixava na geladeira fora roubado, e mesmo que o dono do hotel tenha demonstrado empatia com os Warao, oferecendo café da manhã e, inclusive, compensando-os comprando um novo frango, a situação para a família estava longe das mais confortáveis. Os episódios foram tão desmoralizantes e pareciam sem solução, já que nem a intervenção do dono do hotel parecia suficiente para barrar a vil pilhagem do seu alimento, que Florencia estava decidida a sair do estabelecimento mesmo que significasse pagar um aluguel mais caro ou até morar temporariamente na rua. Florencia queixava-se: "Bom eu quero sair deste hotel. Buscar outro hotel quando acabar este mês. Acho que vamos sair deste hotel porque quando a gente compra o frango e deixa na geladeira, o pessoal vem e rouba" 1 . 2) ou conseguir um apoio financeiro para que Florencia e Rodolfo pudessem voltar de Porto Alegre para Cuiabá onde estão morando atualmente junto com sua família' ${ }^{12 .}$

\footnotetext{
10 A letra da canção que Florencia costuma cantar para pedir dinheiro quer dizer em português: "Os brasileiros são pessoas boas, eles nos recebem bem aqui no Brasil". As canções de Florencia são elaboradas a partir do idioma nativo. Entretanto, para que as letras das suas canções sejam entendidas pelos interlocutores - principalmente quando ela pede dinheiro - é comum que ela cante em espanhol.

${ }^{11}$ Florencia e Rodolfo se comunicam conosco em espanhol. Todas suas falas foram traduzidas pelos autores para o português.

${ }^{12} \mathrm{Na}$ revisão final desse artigo, no dia 8 de outubro, as 14 pessoas que moravam em Cuiabá decidiram tomar um ônibus em direção a Cascavel e logo até Porto Alegre com o plano de juntar dinheiro e logo voltar para Venezuela quando a fronteira abrir. Em Cuiabá ficou um núcleo familiar, encabeçado pela sobrinha de Florencia.
} 
Espaço Ameríndio

Figura 1 - Diagramas de parentesco dos troncos familiares de Florencia relacionados com o local de moradia atual dos parentes, agosto de 2020.

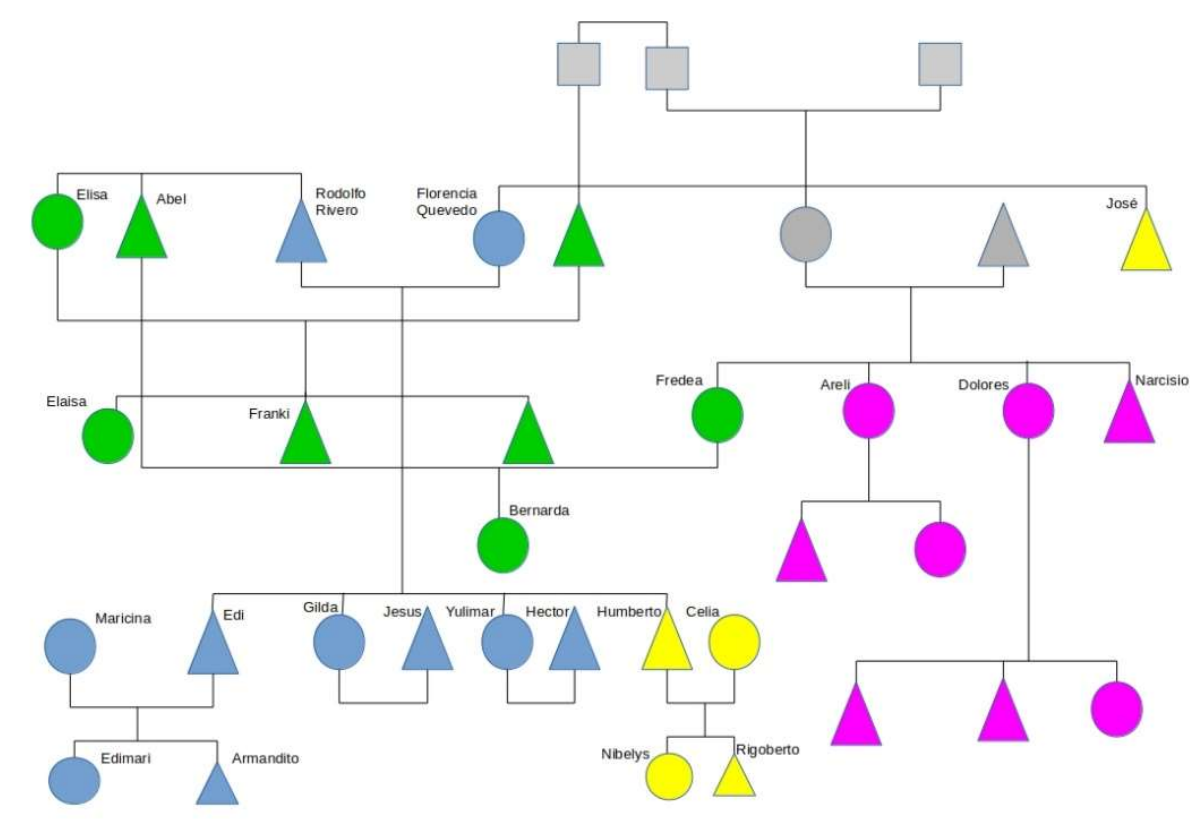

Fonte: Elaboração dos autores.

Figura 2 - Diagramas de parentesco dos troncos familiares de Rodolfo relacionados com o local de moradia atual dos parentes, agosto de 2020.

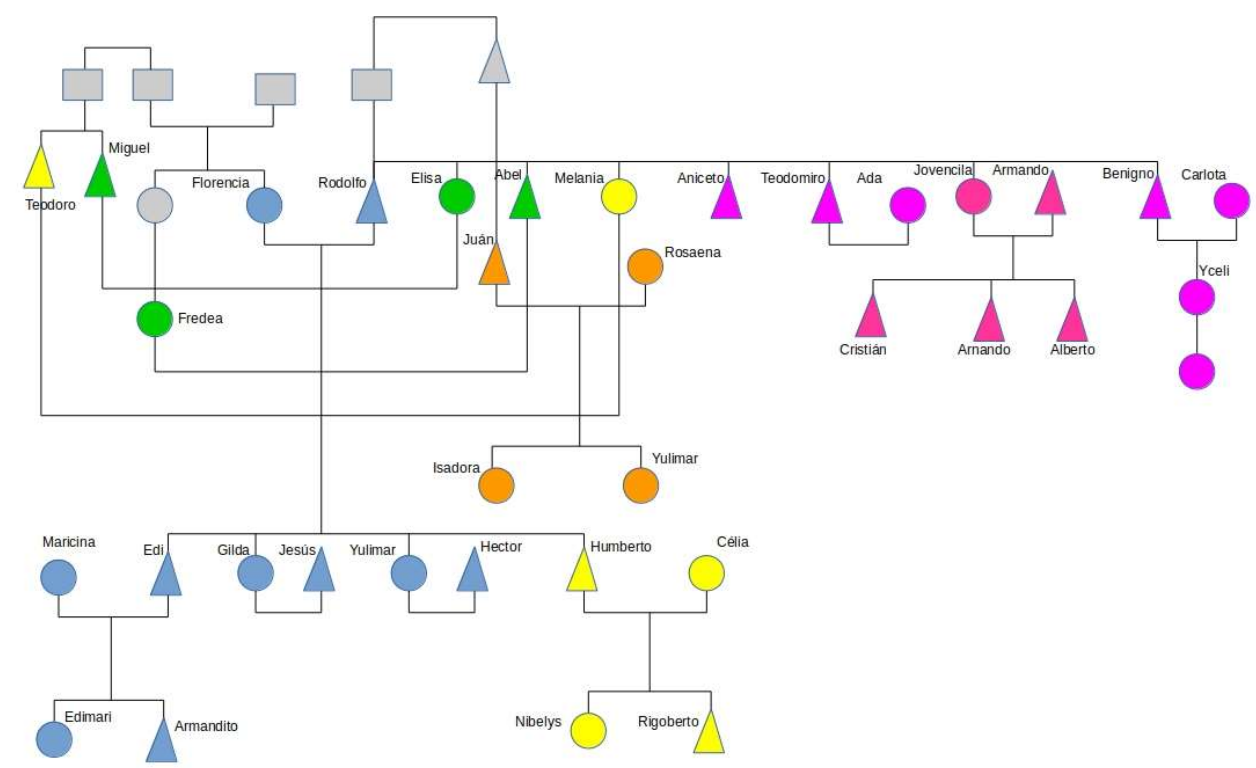

Fonte: Elaboração dos autores. 
Figura 3 - Legenda dos diagramas de parentesco

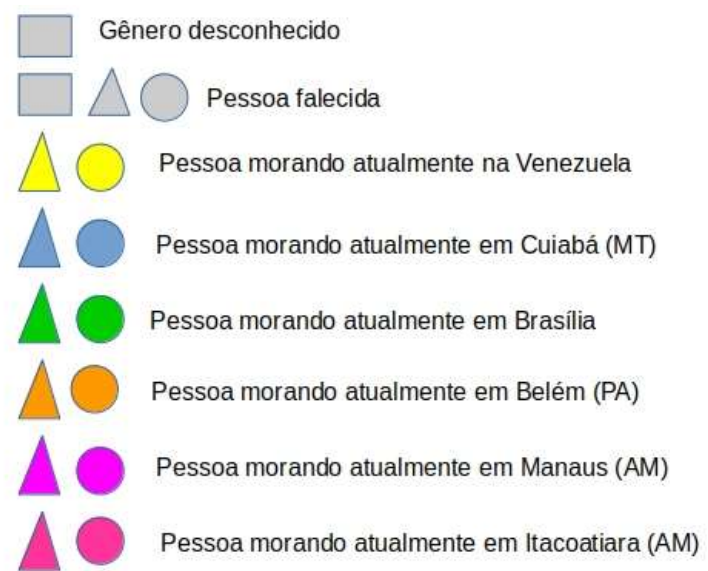

Fonte: Elaboração dos autores.

Contatamos várias instituições e grupos conhecidos por apoiar as causas indígenas, entre elas o Conselho Indigenista Missionário (CIMI), a Secretaria Municipal da Saúde indígena da Prefeitura de Porto Alegre (SMS) e a Unidade dos Povos Indígenas e Direitos Específicos (UPIDE) da Coordenação Geral dos Direitos Humanos (CGDH) da Prefeitura de Porto Alegre, assim como a Secretaria Especial da Saúde Indígena (SESAI) do polo de Cuiabá (MT). Mesmo que a maioria dos funcionários tenha se colocado à disposição para apoiar os Warao respondendo as nossas mensagens, movendo fios por dentro das instituições para conseguir que o mínimo fosse feito, nenhuma solução de longo ou médio prazo foi encontrada para garantir a sobrevivência e a permanência dessa família indígena em Porto Alegre. De fato, a única proposta levada até a família foi a possibilidade de serem transferidos até um albergue para imigrantes em Viamão, gerido pelo Exército Brasileiro. Tendo passado por situações muito precárias em albergues de outras cidades do norte do país ${ }^{13}$, a família declinou o convite sabendo, entretanto, que seguiríamos apoiando-os através do financiamento coletivo e auxiliando-os na conquista do acesso a seus direitos básicos. Assim, ajudamos na realização dos pedidos de Auxílio Emergencial de todos os membros da família de Florencia e Rodolfo. Nossos cadernos de campo foram preenchidos com muitos números de CPF e carteiras de identidade, e passávamos horas no telefone tentando ajudar na resolução de problemas dos quais ninguém parecia ser responsável por resolver. Porém, é justamente esse papel, um tanto contraditório, de "apoiadores", baseado na sensibilidade e na empatia, que abriu as portas para a realização desse artigo construído de forma colaborativa com a família de Florencia e Rodolfo, que enxergaram nesse meio uma maneira de contar

\footnotetext{
${ }^{13}$ Haviam passado por um albergue em Manaus onde o exército operava através da Operação Acolhida. Segundo Florencia, os não indígenas venezuelanos com quem dividiam o alojamento tratavam mal os Warao por serem indígenas. Além de discutir com eles, também lhes roubavam a comida. 
uma pequena parte da sua história: a história dos Warao que chegaram mais ao sul do Brasil.

A família de Florencia e Rodolfo chegou em Cuiabá no começo de agosto de 2019, instalando-se em uma praça perto da rodoviária, onde acamparam. No início da pandemia, o vereador Luís Claudio (PP) resolveu oferecê-los um alojamento pagando os gastos com dinheiro do seu bolso. A situação toda nos intrigava pois Florencia, Rodolfo e seu genro Jesus, mencionavam sempre os seus "encarregados" para se referirem ao pessoal que os alojava e entregava doação de comida. Assim, conseguimos, através de Jesus, o telefone de uma das "encarregadas", uma assistente social que tornar-se-ia secretária da Associação de Amparo à Família Carente, entidade criada pelo vereador que Ihe evitaria ser relacionado pessoal e diretamente com a presença warao em Cuiabá. Tivemos a oportunidade de nos reunirmos online duas vezes com os integrantes da Associação: a primeira com uma das voluntárias e a segunda com a equipe completa, à exceção do vereador. Tínhamos o intuito de conhece-los e nos colocarmos à disposição para o que fosse preciso.

Após vários meses em uma casa, a família extensa warao foi realocada em um novo espaço, mais amplo, que se tornaria a sede da Associação, no bairro Tijucal. Neste contexto, duas assistentes sociais visitam a família diariamente e entregam semanalmente comida e miçanga a pedido dos Warao. A Associação também se responsabilizou pela regularização dos documentos de todos os integrantes da casa, assim como por alguns dos cuidados relativos à sua saúde. A ajuda da Associação é temporária e visa proporcionar um lugar seguro aos Warao durante o período da pandemia. Por isso, ela se disponibilizou a abrigálos em suas dependências até o dia 31 de dezembro, data limite para que a família deixe a casa ${ }^{14}$.

Tal apoio aos Warao foi e continua sendo de uma importância considerável para essas famílias que se encontram em uma situação vulnerável. Entretanto, certas dinâmicas paternalistas e tutelares, assim como os interesses que se escondem por trás da máscara da "ajuda humanitária", mereceriam ser evidenciados e analisados à luz da antropologia $^{15}$. Mesmo que este não seja o foco do nosso artigo, acreditamos que esta situação se espelha na "política de abrigamento" (MOREIRA; TORELLY, 2020, p.48) implementada pelo poder público federal desde 2016, cujos principais objetivos se enraízam numa perspectiva de "limpeza social" das cidades brasileiras, já que as autoridades municipais, estaduais ou federais estão mais interessadas em "tirar os Warao da vista" (RAMOS; TARRAGO; BOTELHO, 2017, p.21) do que elaborar políticas públicas de acolhimento que proporcionem

\footnotetext{
${ }^{14}$ No entendimento dos Warao, porém, a solidariedade dos seus "encarregados" não condizia com nenhum tipo de obrigação. Quando os integrantes da Associação se incomodaram com certas dinâmicas cotidianas dos Warao e intimaram Jesus, considerado por eles como o "encarregado" da família, as tensões se acirraram. Por um lado, os associados consideravam que os Warao deviam cumprir as normas ditadas por eles na casa e ajudá-los nas tarefas da Associação; por outro, os Warao reclamavam que nunca tinham concordado em "ser parte de uma organização".

${ }^{15}$ Sobre uma antropologia da ajuda humanitária ver os estudos de Didier Fassin $(2001,2014)$. 
segurança e dignidade a essa população. Os Warao, considerados como mendicantes, "sujam" a cidade e se convertem em um novo problema social que o poder público e os representantes do governo devem enfrentar. É, sem dúvida, por esse mesmo motivo que há um potente controle social das entradas e saídas dos Warao tanto nos centros de acolhimento pelo Brasil - inclusive antes do surto de Covid-19 -, quanto na casa administrada pela Associação em Cuiabá.

Este artigo busca, a partir de um exemplo etnográfico específico, tornar visível a complexidade e a pluralidade das dimensões que permeiam a situação migratória vivida pelos coletivos warao no Brasil. Escrito a 8 mãos em plena pandemia e atravessado pelos impactos do isolamento social, este trabalho inscreve-se no início de uma pesquisa de antropologia social e histórica. Dessa maneira, os depoimentos e as reflexões apresentadas aqui buscam levantar questionamentos com o intuito de colaborar com pesquisas recentes em torno da mobilidade e da identidade warao no Brasil (ROSA, 2020) em vez de expor conclusões e encerrar argumentos.

Florencia é uma mulher warao de 50 anos. Filha de wisidatu $^{16}$, nasceu nos caños $^{17}$ no estado do Delta Amacuro ${ }^{18}$, "em uma casinha, no morro", como ela mesma diz. Foi sua avó materna que ajudou sua mãe no parto. Seu pai era pescador e coletava ocumo (Colocasia esculenta) ${ }^{19}$ : "meu pai com minha mãe buscavam comida, meu pai sabia pescar e também buscava ocumo", nos relata. Aos 13 anos, foi pela primeira vez até o povoado de Tucupita, no pequeno barco a motor comprado por seu avô. A família ia passar a semana no povoado para comprar comida e voltava para os caños, conforme aponta Florencia: "passava uma semana e depois voltávamos para os caños, comprava comida de criollo: ${ }^{20}$ farinha, açúcar, arroz, pão e refresco." Quando criança, Florencia viu sua mãe

\footnotetext{
${ }^{16}$ Traduzido por Rodolfo e Florencia por "doutor indígena". Segundo o casal, os wisidatu são os únicos que têm a capacidade de espantar os hebu e de curar as pessoas doentes. Eles costumam trabalhar com tabaco e maracas, e são extremamente respeitados pelos Warao, considerados, segundo Rodolfo, como "os que sabem tudo". Cantores, são responsáveis pelos aguaceiros e a queda dos raios. Uma das especialidades dos wisidatu é a realização de massagem, notadamente em pessoas cujos músculos são atrofiados. O cunhado de Florencia, que possuía esse dom, faleceu em Manaus há pouco mais de um ano. Detalharemos no decorrer do artigo. Sobre a figura do wisidatu e o seu lugar na sociedade Warao, ver Briggs (2008) e Wilbert (1993).

${ }^{17}$ Como salienta a antropóloga Marlise Rosa (2020, p.23), os caños fazem referência aos afluentes que compõem o sistema deltaico do rio Orinoco. Assim, são citados para indicar a localização das comunidades, como, por exemplo, caño Winikina, caño Macareo, caño Manamo. Quando os Warao afirmam que "viviam nos caños", significa que viviam na sua comunidade de origem, localizada junto a algum desses afluentes. ${ }^{18}$ Delta Amacuro é um dos 23 estados da Venezuela, sua capital é Tucupita.

19 Uma variedade de tubérculo, introduzida na dieta do grupo a partir da influência de missionários católicos na década de 1920 (ROSA, 2020). Segundo nossa interlocutora Florencia Quevedo, o alimento se parece com um "inhame grande".

${ }^{20} \mathrm{O}$ termo deve ser precisado já que no Brasil toma um caráter diferente do restante da América Latina, em que diz respeito às pessoas nascidas no continente mas com ascendência não ameríndia. Os Warao compartilham desta definição e quando utilizam a palavra criollo, estão se referindo aos não indígenas de qualquer nacionalidade, etnia ou "racialidade" não indígena. No Brasil, crioulo é um termo utilizado para caracterizar de forma pejorativa à população negra e mestiça (RIBEIRO, 1995). Para evitarmos confusão, decidimos manter a palavra criollo, utilizada por nossos interlocutores, no espanhol.
} 
pegar hebu ${ }^{21}$, foi hospitalizada e levada para cidade. Nem os wisidatu, nem os médicos criollos conseguiram curá-la. Faleceu quando Florencia era ainda muito jovem, e ela passou a cuidar dos seus marakubo sanuka (irmãos menores) e das suas maraiba (irmãs menores) junto com seu pai: "meu pai me dizia para cozinhar para minha família, eu cozinhava peixe com ocumo". Foi ali que Florencia se encarregou de najoro (a comida), uma responsabilidade que ela assume até hoje.

Aos 15 anos, conheceu o estado venezuelano de Monagas onde encontrou seu esposo, Rodolfo. O casal voltou por um tempo aos caños, até o ano de 1989, quando Florencia ficou grávida do seu segundo filho, Eddy ${ }^{22}$. Saíram então definitivamente do interior do Delta do Orinoco em Delta Amacuro e se instalaram na cidade de Barrancas. O pai de Florencia resolveu voltar para os caños e Rodolfo começou a trabalhar: "Meu esposo buscava peixe com um senhor. Ele ia pescar durante uma semana e eu ficava sozinha com meu irmão. Quando chegava, chegava com peixe. Vendíamos a pesca e nós comprávamos roupa". Florencia teve 5 filhos e se orgulha de tê-los parido em casa, como ela mesma ressalta: "Nunca dei a luz no hospital, todas minhas filhas, meus filhos pari em casa, nem era uma casa, era um barraco e quando chovia nós nos molhávamos. Nós não utilizávamos fraldas para as crianças, nada disso, só tinha um lençol para colocar na criança, nada mais." As dificuldades em manter uma economia de subsistência nos caños, que se intensificaram com os projetos de desenvolvimento do país, são um dos motivos dos seus deslocamentos temporários ou definitivos para as grandes cidades, seja no interior ou fora do país. Florencia lembra que mesmo após ter se instalado em Barrancas, viajava até Maturín (capital do estado Monagas) ou Caracas para ebú quitane ${ }^{23}$ pedir/exigir dinheiro nas ruas). Dormia junto das crianças nas rodoviárias e, durante o dia, buscava comida e dinheiro nos semáforos e nas ruas, entoando os cânticos warao. A fabricação e comercialização do artesanato realizado com a palma de oji (buriti; Mauritia flexiosa) também se tornou um meio de reprodução econômico e social das famílias warao, que adaptam seu saber-fazer tradicional a este novo contexto migratório.

A trajetória dessa família no Brasil inscreve-se na continuidade de processos de territorialização (PACHECO DE OLIVEIRA, 1998), desterritorialização e reterritorialização (BARBOSA, 2007) oriundos dos avanços de frentes desenvolvimentistas na Venezuela (BELLO, 2005; QUINTERO, 2007) e de uma crise econômica que deixou grande parte dos habitantes do país (indígenas e não indígenas) em situação de

\footnotetext{
${ }^{21}$ Traduzido ora como doença, ora como feitiço ou até como diabo, ele faz referência a um ser invisível cuja atuação é sempre negativa e provoca doenças (visíveis e invisíveis) que podem ser mortais caso o hebu não seja "espantado" por um especialista, o wisidatu. Aprofundaremos no decorrer do artigo.

${ }^{22} \mathrm{O}$ primeiro filho do casal faleceu aos dois anos de idade.

${ }^{23}$ Segundo Florencia e Rodolfo, seisa ebú quitane significa textualmente: "vamos sair para pedir". Segundo o dicionário español-warao online não existe a letra "q" em warao, porém, decidimos sermos fiéis à escrita dos nossos interlocutores. Por outro lado, a palavra ebú refere-se tanto ao verbo "pedir" quanto ao "exigir". Conforme abordaremos adiante através do conceito de demand sharing, elaborado por Garcia-Castro (2018), parece-nos relevante traduzir o conceito de ebú por "pedir/exigir". Fonte: $<$ https://pueblosoriginarios.com/lenguas/warao.php>. Acesso em 19/09/2020. 
vulnerabilidade, forçando-os a atravessar fronteiras em busca de alimentos, medicamentos e trabalho.

\section{Breve contexto histórico das migrações warao}

Constituídos originalmente há mais de oito mil anos na região do delta do rio Orinoco, os Warao são o grupo humano mais antigo do atual território da Venezuela (GARCíA CASTRO, 2006). Pertencem a um tronco linguístico independente, dividido em quatro dialetos, com um sistema de parentesco matrilinear e residência uxorilocal. A economia tradicional warao está baseada na atividade pesqueira e na exploração microambiental de recursos locais - principalmente a palma de buriti, por eles denominada oji. Até o início do século XX esta dependia totalmente dos recursos naturais da região (AYALA LAFÉE-WILBERT; WILBERT, 2008, p.46).

Diversos processos históricos, que iniciam na década de 1920, acarretam intensas transformações sociais e ecológicas na região deltaica. Começando pela introdução do cultivo de ocumo chino nas regiões onde tradicionalmente se realizava a exploração do oji, resultando em uma escassez de alimentos e no início de uma relação de dependência do trabalho assalariado (ROSA, 2020, p.72). Na década de 1960 ocorre o fechamento do caño Manamo, um projeto tecnocrático realizado com o intuito de promover o desenvolvimento da região por meio da abertura de terras para agricultura ${ }^{24}$. Esse empreendimento levou a uma série de problemas aos grupos ribeirinhos, dentre os quais estão as doenças transmitidas pela água e o desaparecimento de animais e plantas que garantiam certa autonomia para essas populações. 0 fechamento do caño inviabilizou assim atividades como a pesca, a caça e a coleta, ocasionando também a ruptura do sistema de trabalho encabeçado pela figura do sogro/chefe ${ }^{25}$. Os Warao tornaram-se, dessa maneira, um excedente de mão de obra não qualificada (GARCIA-CASTRO; HEINEN, 1999, p. 48). Além disso, estes projetos de caráter desenvolvimentista levaram uma série de doenças até a população indígena delta-amacurenha. No final do século XX, um surto de cólera nos caños provocou o aumento do êxodo para os centros urbanos e, em 2011, $12,78 \%$ dessa população residia em cidades como Barrancas e Tucupita, capital do estado Delta Amacuro. (GARCIA-CASTRO, 2018, p. 35).

No decorrer desse movimento, foram se estabelecendo novas estratégias de organização social e, também, novas dinâmicas econômicas, que trouxeram certas práticas tradicionais para dentro do

\footnotetext{
${ }^{24}$ É importante ressaltar que em nenhuma etapa do projeto as populações indígenas da região foram consultadas, havendo até mesmo desconhecimento de sua existência por parte dos responsáveis pela obra (GARCIA-CASTRO; HEINEN, 1999, p. 40).

${ }^{25} \mathrm{O}$ sistema socioeconômico tradicional nas comunidades warao baseava-se em um princípio de reciprocidade centrada nos laços de parentesco. A organização da força de trabalho era feita pelo aidamo (sogro/chefe) e a repartição do produto realizada por arani (sua companheira). A partir do rompimento dessa relação criam-se, em seu lugar, grupos de trabalhadores individuais agrupados por famílias nucleares, dirigidos agora pelos genros, que atuavam como intermediários, em substituição ao sogro ou aidamo. (GARCIA-CASTRO, HEINEN, 1999, p.48) 
contexto urbano (GARCÍA-CASTRO, 2000, p. 85). A partir de 2016, devido ao aprofundamento da crise econômica na Venezuela, tem se verificado a entrada de diversos indígenas warao, além de outros povos indígenas originários da Venezuela, em território brasileiro (QUINTERO, 2020). Em uma reunião online promovida pela Organização Internacional para as Migrações (OIM) e realizada em 16 de junho de 2020, lideranças warao contabilizaram pelo menos 4900 indígenas do seu povo no Brasil. Entretanto, por conta da dificuldade de mapear os Warao no Brasil, é muito provável que estes números sejam significativamente maiores.

Como afirmaram Garcia-Castro (2000) e Ayala Lafée-Wilbert e Wilbert (2008, p.99), as viagens realizadas pelos Warao até os centros urbanos têm como principal objetivo a obtenção de recursos econômicos que, uma vez adquiridos, possibilitam o retorno às comunidades de origem $^{26}$. Esse movimento é verificado, em certa medida, também no Brasil, uma vez que, como ressalta Moutinho $(2017$, p. 8) ele "se reflete na oscilação da quantidade de indígenas nas cidades brasileiras", dado que "uma questão que muito os preocupa [os Warao] é se havia garantias do direito de ir e vir através da fronteira Brasil/Venezuela"27 (RAMOS; BOTELHO; TARRAGÓ, 2017, p. 24). Esse deslocamento contínuo entre os dois países pode ser explicado por diversos fatores. Os principais parecem surgir: 1) da necessidade de levar alimentos e recursos para os parentes que ficaram na Venezuela; 2) do intuito de coletar materiais para a produção de artesanato que são mais facilmente obtidos em território venezuelano ${ }^{28}$; 3) de trazer os parentes que ainda permanecem na Venezuela para o Brasil. Parece comum entre os Warao que um núcleo específico de uma família extensa fique na Venezuela para cuidar da casa e pertences familiares. No caso da família de Florencia e Rodolfo, como podemos observar nos diagramas de parentesco acima, um dos seus filhos ficou na Venezuela junto à sua esposa e aos seus dois filhos. Porém, ele já tinha vindo ao Brasil, o que nos leva a pensar que pode existir certa "rotatividade" entre os núcleos familiares que moram no Brasil e os que ficam na Venezuela.

Além do movimento entre Brasil e Venezuela, verifica-se entre os Warao que já estão no Brasil uma grande mobilidade entre os centros urbanos brasileiros. Vale a pena ressaltar a extrema vulnerabilidade na qual se encontram os Warao nas cidades brasileiras, expostos tanto à violência das instituições quanto da sociedade civil. Costumam acampar em terrenos próximos a rodoviárias ou alugam casas ou quartos em

\footnotetext{
${ }^{26}$ A fim de exemplificar, os autores trazem um depoimento de J.M España: "Com esse dinheiro que sobrou (...) temos o que comer por quatro ou cinco meses. Quando acaba o dinheiro voltamos para as cidades para trabalhar procurando trocado. Assim temos que fazer para ter um pouquinho de roupa e comida" (E. P. BARRANCAS. in: AYALA, LAFÉE-WILBERT; WILBERT, 2008, p.133)

27 Rosa (2020, p.38) busca diferenciar migração forçada e refúgio, destacando que apenas a segunda categoria dispõe de mecanismos institucionais para a obtenção de direitos garantidos. A migração venezuelana refere-se a uma migração por sobrevivência, uma situação, porém, não respaldada legal e institucionalmente. Dessa maneira, apesar de não se considerarem refugiados - pois podem voltar para Venezuela - os venezuelanos (incluindo os Warao) solicitam na Polícia Federal (PF) o status de refugiado, podendo, assim, conseguir a regularização dos seus documentos.

${ }^{28}$ Mesmo que os Warao encontrem palma de oji no Brasil, alguns deles nutrem certo receio em coletar o material em espaços que são considerados "privados". 
pensões com localização central, estando sujeitos a preços abusivos por parte dos proprietários que tiram vantagem da situação na qual se encontram os indígenas (ROSA, 2020, p.159).

Para "resolver" os fluxos migratórios dos indígenas venezuelanos, o governo brasileiro realizou uma série de deportações em massa entre os anos 2014 e 2016 (RAMOS; TARRAGO; BOTELHO, 2017, p.23). Isso surge como resposta à demanda de certo setor da sociedade civil que se incomodou com a presença de venezuelanos no território nacional afirmando, por exemplo, que: "vem sendo abordada por pedintes, indígenas estrangeiros e outras pessoas oriundas de países de fronteira que não apresentam documentação legal para permanência em solo brasileiro" (MOUTINHO, 2017, p. 9).

A partir de 2016, a "política de abrigamentos" torna-se "a principal política promovida até o momento pelo poder público federal, estadual ou municipal para a população indígena no fluxo migratório venezuelano" (MOREIRA; TORELLY, 2020, p. 66) ${ }^{29}$. Esta política tem fomentado uma situação de dependência para essas populações que se encontram submetidas a condições de vida degradantes nos albergues e alojamentos que geralmente são administrados pelo exército brasileiro. Assim, a mobilidade warao dentro do território brasileiro deve ser entendida como uma resposta a essas condições de vida, muitas vezes insalubres e permeada pela violência, associada a uma histórica forma de resistência e ação política diante inúmeras intervenções em seus territórios. Este é o caso da família warao cuja trajetória este artigo busca retratar.

A partir da nossa etnografia, destacamos 3 elementos centrais e entrelaçados que parecem atravessar a (re)organização social, econômica e espiritual da família de Florencia e Rodolfo na situação do seu deslocamento para o Brasil. Primeiramente, a busca por najoro (comida), que se constitui como um dos principais argumentos dos Warao para atravessar a fronteira com o Brasil, considerado um lugar de abundância em relação à escassez na Venezuela. Além disso, a trajetória enquanto cozinheira de Florencia tem reforçado a importância da comida nas suas dimensões sociais e coletivas (coesão e fortalecimento do tecido social), além das suas relações materiais (segurança alimentar própria e da família extensa que se encontra espalhada por diversos locais no Brasil e na Venezuela ${ }^{30}$ ). Em segundo lugar, as doenças, que para os Warao têm sua origem na atuação dos hebu ou hebu zabana, ${ }^{31}$ e formam parte do cotidiano desses coletivos no Brasil. Invisíveis aos olhos do governo e da

\footnotetext{
${ }^{29}$ Os abrigos possuem suas próprias normas e regras de convivência que, caso não cumpridas, podem acarretar a expulsão. Também existe um limite máximo de três meses para a permanência (MOREIRA; TORELLY, 2020, p. 67). A interlocução entre os indígenas e as autoridades institucionais é feita por meio dos aidamo, lideranças escolhidas pelos próprios Warao para serem as responsáveis pelas demandas e resolução de conflitos. Na prática, o que ocorre é a transferência de indígenas para abrigos públicos em bairros afastados, os quais não tem estrutura para recebê-los de forma eficiente, contando com diversos problemas estruturais e superlotação (MOUTINHO, 2017, p. 10). Outro fator problemático constantemente denunciado pelos Warao que estão nos abrigos é a presença conjunta de imigrantes indígenas e não indígenas no mesmo espaço, acarretando conflitos e complicações. Para um aprofundamento etnográfico das dinâmicas dos abrigos e suas consequências para a população Warao ver Rosa (2020).

${ }^{30}$ Os laços de parentesco constituem-se como um dos motores da organização social no contexto migratório.

${ }^{31}$ Segundo Rodolfo, o coronavírus é um hebu zabana, isto é, uma doença perigosa.

MARÉCHAL, Clémentine; VELHO, Augusto Leal de Britto; RODRIGUES, Milena Weber; BUENO, Pietro. Transformações sociais e (re)territorialização Warao no Brasil: a trajetória de uma família frente à pandemia de covid-19. Espaço Ameríndio, Porto Alegre, v. 14, n. 2, p. 46-87, jul./dez. 2020.
} 
sociedade brasileira, as famílias warao costumam receber uma assistência de saúde de péssima qualidade, ou nenhuma. Muitos são os relatos de familiares warao que adoecem e morrem nos hospitais brasileiros ${ }^{32}$. Dessa maneira, a morte e a doença, sempre entendida como resultado da chegada de um ou vários hebu, tem acompanhado os Warao nas suas caminhadas pelo país. Abordaremos, a partir da trajetória da família de Florencia no Brasil, a importância dos hebu e dos wisidatu no seu entendimento das doenças e das formas de combatê-las, e veremos como o pensamento mítico warao vem se reinterpretando e reelaborando à luz das condições impostas pela situação de migração, assim como através da realização de rituais que passam a adotar novos significados. $O$ último elemento diz respeito às estruturas materiais de sobrevivência (QUIJANO, 1998) construídas pelos Warao ao longo das suas caminhadas pela Venezuela e pelo Brasil. Longe de poder ser considerado como mendicância, os "pedidos" das mulheres warao nos semáforos, acompanhados dos seus cantos, que se transformam no decorrer das suas interações, devem ser entendidos como um meio de reprodução econômico, controlado exclusivamente pelas mulheres e que merece uma atenção particular. Identificamos também outras relações capital/trabalho entre os Warao que, enquanto indígenas e migrantes, se constituem como uma reserva de trabalhadores de baixo custo cuja incorporação ao sistema capitalista ocorre mediante sua inserção num duplo mercado de trabalho (MEILLASSOUX, 1975).

\section{Comensalidade na (re)construção das identidades warao em contexto migratório}

"Antes sim havia comida nos mercados, as prateleiras eram cheias, cheias de comida, assim como aqui no Brasil. Mas hoje já não é assim", conta-nos Florencia durante uma ida até um supermercado no centro de Porto Alegre, no começo da pandemia. A escassez de comida nas comunidades warao, seja nos seus bairros urbanos ou nos caños do delta do Orinoco, é um dos fatores que motivam esses deslocamentos mais recentes, a primeira transnacional de que se tem registro. A alimentação constitui-se, portanto, como um pilar da organização social atual dos Warao, sendo um dos principais argumentos levantados por eles para explicar seus deslocamentos. Na medida em que se compreende a centralidade da comida na mobilidade warao, podemos entender melhor as estratégias, objetivos e transformações que acometem os grupos que hoje se encontram no Brasil. A comida e os processos que a acompanham, desde o movimento de coleta até sua partilha e ingestão, constitui um elemento central em cada sociedade, comumente analisado pelas ciências sociais através do conceito de comensalidade, com o intuito de entender as funções sociais dos alimentos. Neste sentido, tanto a escolha da comida como os hábitos de preparo e consumo são atravessados pela

\footnotetext{
${ }^{32}$ A própria irmã de Florencia e seu cunhado faleceram em um hospital de Manaus. A antropóloga Marlise Rosa (2020, p.85) aponta que entre 2017 e junho de 2020, somam-se um total de 66 mortes de indígenas warao no Brasil. 
história e pela cultura de cada sociedade, indivíduo ou grupo social (MINTZ, 1986). A partir da trajetória de vida de Florencia, podemos analisar algumas preferências e opções alimentares, bem como o processo de preparo de pratos e ingredientes que são servidos e compartilhados com os demais. Cabe ressaltar que esta escolha não é casualidade, pois a comida é também uma das grandes paixões da nossa interlocutora, que se orgulha de ser cozinheira, já que em sua prática culinária convivem tradições diferentes que merecem uma atenção particular. Desse modo, é importante enfatizar que alguns dos alimentos preparados e consumidos por Florencia e sua família não são necessariamente consumidos por todos os grupos warao mas, sem dúvida, se relacionam com a reconstrução das identidades desses grupos ao longo de seus deslocamentos.

Apesar de ter começado a cozinhar nos caños, território tradicional warao caracterizado por suas redes fluviais sobre as quais constroem suas janoko (residências), Florencia, quando se muda para um pueblo ${ }^{33}$ em Barrancas, começa a ter mais contato com os costumes criollos. Incorpora, por exemplo, o café da manhã como uma refeição, o que antes não acontecia, pois, segundo ela, para comer como os apoho warao ${ }^{34}$, há que se realizar apenas duas refeições ao dia: uma pela manhã, com comida de verdade (diferentemente dos hábitos criollos as duas refeições são igualmente nutritivas, cozidas e servidas quentes); e outra no final da tarde, a janta, já que os apoho warao dormem cedo. Anos mais tarde, quando já era casada e tinha filhos, recebeu uma proposta de trabalho para ser cozinheira da escola Indígena Municipal de Barrancas. Para cozinhar para as 150 crianças, participou de um curso preparatório que marcou sua vida.

Quando eu cheguei em Barrancas, quando eu conheci o Rodolfo, aí eu ainda comia sem aliño. Mas, depois de anos, eu fui trabalhar na escola, e um padre me disse para ir fazer o curso para ir cozinhar. Me fez fazer curso para cozinhar, aí sim eu aprendi com as verduras tudo para cozinhar. Fui para Maturín, onde haviam quatro senhoras que me perguntaram se era indígena, e falaram que iam me ensinar a cozinhar. 'Veja como vou cozinhar para que cozinhe assim para as crianças na escola'. Me apresentou todos os aliños, o frango... E eu ficava sentadinha assistindo elas para fazer igual para as crianças em Barrancas. 'Pode cortar o frango, o aliño...' Me deu estes conselhos. Então não aprendi sozinha, fui fazer curso. Daí depois desse curso aprendi cozinhar, e

\footnotetext{
${ }^{33}$ Pueblo é um termo usado para se referir aos diferentes conjuntos de casas ou de famílias morando juntas na cidade de Barrancas.

${ }^{34}$ Nos caños do Delta do Orinoco, diz-se apoho warao para o que denominam "indígenas verdadeiros". Florencia, ao mesmo tempo que considera a si e a seus descendentes nascidos fora dos caños como apoho warao, afirma que os indígenas que ainda vivem com contato limitado com criollos e suas comidas, nos caños, são mais "apoho warao" do que os que migraram em direção às cidades. Tal categoria deve ser, assim, lida como um referencial relacional, como aponta Frederik Barth (2011), pois é através das interações que a etnicidade se manifesta. Para o caso da heterogeneidade da identidade Warao ver Gassón e Heinen (2012). 
fui cozinhar para a escola. Eu ainda falo com uma secretária da escola que disse que, se eu voltar, ainda posso trabalhar lá na escola, graças a Deus! (Florencia Quevedo, março de 2020).

O aliño nada mais é que tempero, mas se constitui como uma linha divisória entre a comida considerada como de apoho warao e a comida considerada hotarao ${ }^{35}$. A fórmula básica do aliño de Florencia é a cebola picada, a cebolinha e o pimentão verde, um pouquinho de alho às vezes aparece. Segundo ela, o aliño deve ser o mesmo sempre. Usa-o no peixe, no frango, nas sopas, para fazer o molho do macarrão, e também no feijão-preto, que chamam de caraota, e que leva um pouquinho de açúcar no preparo, demonstrando a influência da tradição caribenha na cozinha criolla dela.

Por conta deste aprendizado, hoje considera que sua comida é criolla. Quando perguntada sobre quando começou a preparar alimentos para a família, ela relata as longas viagens de canoa com seu pai, e quando sua mãe trazia lenha para cozinhar dentro da canoa aquilo que o pai pescava. Contudo, passa a considerar-se cozinheira de fato depois de concluir o curso em Maturín, quando começa a usar o aliño. O que marca mais a passagem de uma chave culinária para outra não é o uso de um fogão convencional versus o uso de madeira para cozinhar, mas sim o uso ou não dessa mistura de temperos básicos, fundamental hoje em quase tudo que cozinha:

Quando estava nos caños, não cozinhava assim. Cozinhava sem aliño. Comíamos por lá ocumo com peixe, nada mais. Cozinhava as sopas sem aliño. Ainda eu cozinhava com minha mama para meu papa sem aliño. Lá nos caños não tem o aliño. Lá comia o peixe feito na lenha e cozinhava assim. Meu pai ia de canoa e buscava peixe. Chegava na casa e cozinhava ou assava o peixe, mas sem aliño (Florencia Quevedo, junho de 2020).

Outro elemento importante é a forma pela qual a "escola" culinária warao se atualizou no último século com a inserção por parte dos padres capuchinhos do ocumo chino, que compõe a principal fonte de carboidrato na dieta de Florencia e sua família. Desde sua criação nos caños, o ocumo está presente na sua alimentação, principalmente acompanhando o peixe tanto ensopados como, depois, também frito. Hoje, no Brasil, o ocumo vem perdendo lugar na mesa de Florencia pela dificuldade de ser encontrado ou por não se tratar da mesma variedade que existe na Venezuela. Dessa maneira, o ocumo foi substituído principalmente pelo que eles chamam de yuca ou macaxeira (manihoc esculenta): "hoje estamos cozinhando frango de sopa, com banana e macaxeira", nos relata Florencia. Ela cozinhou pelas primeiras vezes ainda quando vivia nos caños, nisso que ela denomina cozinha indígena, comida

${ }^{35}$ Hotarao se refere a qualquer pessoa ou elemento que não é considerado como warao. 
indígena, ou najoro. Isso parece ter marcado muito os paladares da família: o prato favorito do casal é o peixe assado, algo que comiam já quando crianças nos caños, e a bebida favorita é o suco de oji. Assim, elementos indígenas, criollos venezuelanos e criollos brasileiros convivem, de alguma forma, na cozinha de Florencia. Apesar da introdução de novíssimos elementos em sua dieta - como o aumento do uso do frango, do macarrão e do arroz, bem como da adoção da mortadela ou de espécies novas de peixe, antes desconhecidas, nas suas receitas -, é possível ouvir o eco da comida warao quando se fala em aru (algo similar à tapioca), de suco de oji, ou humataba ebuá (peixe assado).

Florencia é muito orgulhosa dos conhecimentos e das práticas da culinária criolla que aprendeu. Entretanto, essas mudanças na sua cozinha levam-na a refletir sobre os processos que a fizeram transformar sua culinária: "Essa é a comida que nós estamos comendo, igualzinha à dos criollos, será que assim está bem? Eu cozinhar assim?", ela questionou em uma entrevista, após descrever algumas das suas receitas. Segundo Florencia, a saída dos caños descaracterizou a sua alimentação e sua cozinha, antes baseada somente em ocumo, derivados de oji sazonais e muito peixe, feito assado na lenha - que Rodolfo diz ficar bom porque todos os óleos do peixe caem sobre a brasa - ou cozido, pois nos caños não tem fogão. E como também, "não tem carro, nem moto, assim tem só canoa; só canoa lá nos canaletes", como disse Rodolfo, o único tempero que usavam por lá, o sal, chegava de barco dos pueblos próximos.

Najoro isabanoko, palavra warao para "cozinha", parece ser um domínio feminino e, mesmo em uma situação de migração e intensa mudança social, vislumbramos uma importante divisão sexual do trabalho no seio da família de Florencia.

Eu gosto de cozinhar sim mas eu cozinho para minha família. Eu faço peixe, [...] eu faço para comê-lo com minha família. Eu também faço frango refogado, coloco na sopa, assim a sopa fica boa. Eu a como com minha família, faço na panela grande desse jeito eu faço pra minha família. [...] Aliños, sempre uso os mesmos, nunca mudo meus aliños nada disso, eu coloco a cebola, cebolinha, e pimentão. E aí refogo um pouquinho o macarrão para comer com frango assado, para minha família, para a cozinha. Assim eu cozinhava também na Venezuela para as crianças da escola. [...] a caraota é a negra assim eu cozinho, eu como assim (Florencia Quevedo, junho de 2020).

Percebemos através do relato que uma das preocupações centrais de Florencia é a circunstância em que o prato deve ser consumido, isto é, sempre em família. As receitas são importantes, mas o peso maior é o ato de alimentar a família, de estender para seus parentes a mesa e, assim, compartilhar os pratos que elabora com dedicação. Comer em família é a parte mais importante, elemento comum para todas suas receitas. Na sua cozinha, o caráter familiar das refeições é o cerne que permanece: 
cozinhava desde pequena nos caños para seu pai e seus irmãos; depois para seus irmãos e Rodolfo, e hoje, no Brasil, cozinha para todos os seus familiares que vivem em Cuiabá. Seja alimentando seu pai durante as suas viagens de vários dias de canoa, ou sua família se deslocando até o Brasil, Florencia sempre serve a mesa, tendo que adaptar sua cozinha aos diferentes costumes culinários do Brasil - ingredientes, preços, cozinhas e fogões. Como aponta Carneiro (2003), a sociabilidade manifesta-se sempre na comida compartilhada. Porém, para Florencia, alimentar a família não se restringe ao seu círculo geograficamente próximo e, de fato, a sua maior preocupação, o maior motivo de sua angústia, é a fome que passam seus filhos e netos que ficaram na Venezuela.

Porque eu estou aqui fazendo 3 refeições por dia enquanto eles lá, meus filhos, meus netos, mal conseguem fazer uma, eu estou muito bem aqui, só queria poder mandar comida para lá de aqui para que eles não tenham mais fome, me dói muito isso de não conseguir ajudar eles, de só conseguir mandar reais de vez em quando, quando o real chega lá eles só pegam comida direto só isso (Florencia Quevedo, junho de 2020).

Como Florencia aponta, no Brasil tem muita comida. Então o ideal é que se envie parte dos alimentos para Venezuela com a finalidade de sustentar os familiares que permanecem do outro lado da fronteira, muitas vezes em situação de vulnerabilidade social. Ela descarta a possibilidade de acumular dinheiro enquanto seus parentes não estiverem em situação definitivamente confortável. ${ }^{36}$ Até lá, Florencia diz que vai enviar tudo que ganha em suas saídas de ebú quitane para que tenham comida na Venezuela. Essa é sua mesa estendida ${ }^{37}$, que alimenta no Brasil e tenta alcançar também a Venezuela. Nesse sentido, no contexto de deslocamento vivido pelos Warao, a comensalidade se estende além dos alimentos materialmente compartilhados. A mesa estendida da família se reverbera através das mensagens de aplicativos, e da possibilidade de demonstrar o vínculo afetivo entre alimento e os membros da família que, embora afastados fisicamente, recordam momentos vividos juntos e compartilham novos, nos quais a forma de ser warao no Brasil é reafirmada ao mesmo tempo em que se reinventa.

Elisa, irmã de Rodolfo que reside em Brasília, compartilhou, com seus familiares que estão atualmente em Cuiabá, vídeos de um balde cheio de caranguejos vivos e outro dela degustando-os com o marido, celebrando sua conquista. O contentamento com os caranguejos foi tamanho que a mesa foi estendida até nós, que também recebemos os vídeos. Isso foi motivo de grande curiosidade da nossa parte por duas

\footnotetext{
${ }^{36}$ Os planos futuros da família se alternam com frequência: às vezes sugerem retornar à Venezuela e, em outros momentos, planejam enviar apenas um familiar para averiguar a situação dos membros que ficaram do outro lado da fronteira e cuidam da casa deixada para trás. Em outras vezes, os planos apontam para uma longa permanência no Brasil.

${ }^{37}$ A mesa estendida pode ser considerada como um sinônimo dos conceitos de "reciprocidade estendida" ou demand sharing desenvolvidos por Álvaro Garcia-Castro (2018). Aprofundaremos mais adiante. 
Espaço Ameríndio

razões: por se tratar de uma comida muito apreciada entre os Warao na Venezuela, mas também por imaginar como ocorreu deu o acesso a este alimento, facilmente encontrado nos manguezais venezuelanos.

Sim, nós comíamos caranguejos, não é todos os dias, sim comíamos em agosto, que em agosto fica abundante, as pessoas vão buscar perto do mar e se come muito. Se tem motor vão lá se não vai de canoa buscar. Cada agosto se faz isso, 15 de agosto, mas depois disso não tem mais, cada ano se comia (Rodolfo Rivero, junho de 2020).

É difícil imaginar uma coleta de caranguejos por indígenas warao no planalto central. Porém, a vontade de comer atrelada à saudade de outros tempos desperta nos Warao forças colossais capazes de mover crustáceos. A paixão dos Warao por caranguejo é tão grande que, segundo Briggs e Mantini-Briggs (2016), foi um dos vetores importantes da cólera entre os Warao, que por seu hábito de comer caranguejos foram mais infectados que os hotarao da região dos caños nos anos 1990. Aqui no Brasil Florencia já havia perguntado sobre nosso consumo de caranguejo - contudo, em Porto Alegre não há esse costume (no máximo escassos siris no litoral gaúcho).

Imagem 1 - Irmã de Rodolfo e familiares comendo caranguejos em Brasília.

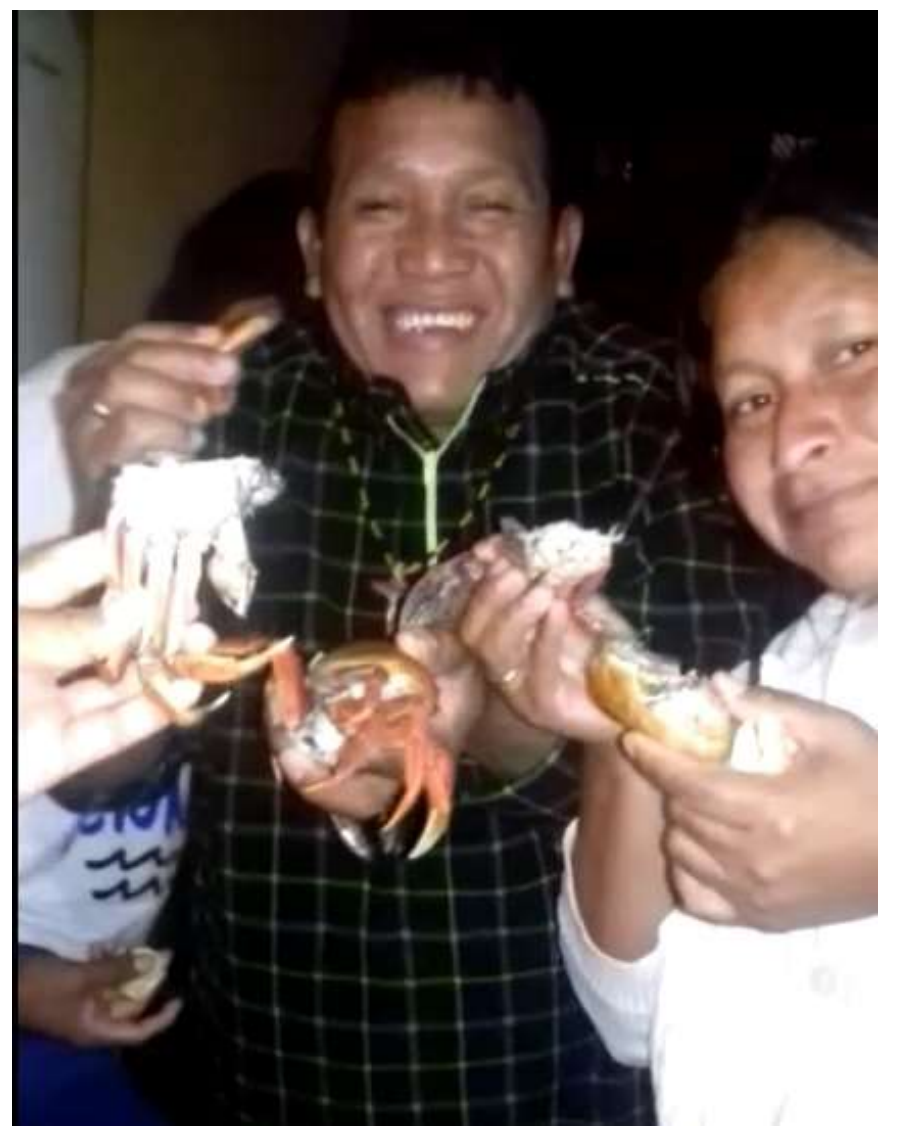

Fonte: Fotografia enviada aos autores, agosto de 2020. Autor desconhecido 
Descobrimos, por fim, que uma interessante coincidência pode ser responsável pelo acesso dos Warao ao seu amado crustáceo em Brasília. Assim como os indígenas venezuelanos, os migrantes oriundos do nordeste brasileiro e seus descendentes - que compõem grande parte da população de Brasília e cidades vizinhas - são comedores ávidos de caranguejo, uma iguaria do litoral. Assim, para suprir a demanda candanga por caranguejos, existe um comércio local bem estabelecido. Restaurantes, peixarias, distribuidores e até fazendas de produção de crustáceo podem ser encontrados no Distrito Federal. Encontramos uma vez mais um dos aspectos característicos da comensalidade warao atrelada a situações de deslocamento: uma mesa estendida de belos caranguejos azuis - comprados tão frescos que estavam vivos em vídeo que tem de ser consumidos em família e compartilhados, mesmo virtualmente, para todos sentirem um pouco o gostinho de casa.

Antes da pandemia tornar nossas visitas mais esporádicas, conduzimos algumas entrevistas com Florencia e Rodolfo. Geralmente, comprávamos juntos comida e bebida para ajudar com os preços altos que estavam pagando por sua hospedagem na capital gaúcha, e notamos que uma unanimidade em termos de bebida na família sempre foi a CocaCola. Dias depois, em uma chamada telefônica, aproveitando um relato de Florencia sobre as bebidas consumidas nos caños, fizemos uma pergunta para ela e nos foram descritas as maravilhas do suco de oji:

- Afinal do que gosta mais: Coca-Cola ou suco de oji?

- Ah, de suco de oji, claro! É nossa bebida favorita de todas, mas só tem lá na Venezuela.

O oji, que aqui conhecemos por buriti, faz parte integral da economia warao. Além de ser a principal fonte de carboidratos na alimentação, também serve de matéria prima para o artesanato daqueles que vivem nos caños. A palmeira também é usada, por suas folhas e madeira, na construção civil warao, principalmente dos janoko. Florencia conta que tanto ela como seu marido, durante a infância e juventude nos caños, faziam parte dos coletivos de coletores de oji que se deslocam para as ilhas alagadas, incontáveis no delta do Orinoco, em determinadas estações, onde faziam a coleta da matéria-prima. Florencia relata que, além das frutas que dão o ano inteiro e rendem bastante suco de oji, também gostava muito dos mojo (larvas) que se recolhem de dentro da palmeira, de onde se retira, também, o $a r u$, que Rodolfo diz ser praticamente igual à nossa conhecida tapioca. Uma refeição completa, portanto, pode sair de uma palmeira de oji: aru com recheio de mojos, palma e suco de oji para acompanhar.

O suco de oji é considerado pelos Warao como sua principal fonte de alimento tradicional. Segundo Florencia, o suco tem uma qualidade soporífera ativada logo após sua ingestão, o que causa à pessoa que toma, o imperativo de dormir em qualquer lugar, até na canoa. Impossibilitados de consumir a bebida, Florencia dá novos significados ao alimento, consolidando, assim, uma memória afetiva compartilhada com os outros Warao. Esta memória está na origem da (re)elaboração das 
identidades warao, que deve ser lida a partir do contexto migratório no qual se redefinem códigos de pertença étnica, ora valorizando hábitos tradicionais que pelas circunstâncias não podem ser reproduzidos, ora (re)inventando práticas sociais. Entretanto, a menção ao suco de oji como "bebida favorita" dos coletivos warao, longe de fazer referência a um passado longínquo e inalcançável, segue a história coletiva e as intencionalidades (GALLOIS, 2008, p.35). Nesse sentido, tal referência ao suco de oji, articulada com a adoção do consumo diário de Coca-Cola, expressam as tensões vividas pelos Warao entre perenidade e flexibilidade, de modo que a memória afetiva deve ser entendida tanto como um impulso para a construção do futuro quanto um dos motores da redefinição das identidades warao no contexto de migração. Esta tensão se expressa, também, nos questionamentos de Florencia quando, como vimos, ela se pergunta se a "criollização" da sua comida é algo "certo". Tais dúvidas e perguntas afirmam o caráter processual e transformador das culturas e das identidades que, diante dos contextos, se reconstroem e ressignificam.

A comensalidade entre os Warao no Brasil parece se atrelar às relações de parentesco e se reverberar nos laços de amizade e nas interações que vêm se elaborando nos caminhos traçados por eles. Alimentar a família, seja mediante o ato de cozinhar, seja enviando dinheiro para os familiares que precisam, assim como "ser alimentado" pelos parceiros (a Associação, os amigos e instituições públicas), através de financiamento coletivo, ajuda humanitária e doação de comida, se articula, a nosso ver, com a ideia de reciprocidade estendida ou demand sharing desenhada por Garcia-Castro (2018). Quem tiver najoro (comida) ou burata (dinheiro) sobrando, deve compartilhar. Nesse sentido, a ausência de najoro - principalmente do peixe e do frango - na mesa dos Warao, enquanto as prateleiras estão cheias nos supermercados, pode chegar a debilitar o equilíbrio social do coletivo e favorecer, assim, a chegada de um ou vários hebu, o que pode colocar em perigo o coletivo ou alguns dos seus integrantes.

Alguns dias antes de Florencia e Rodolfo retornarem a Cuiabá, seu genro, Jesus, comentou por telefone que, na casa onde morava a família, tinha aparecido um hebu. O ser extra-humano, que será descrito logo por Florencia como "um menino pequeno com uma pata só", tirava o sono da família, que considerou seriamente retirar-se da casa ainda que tivessem de voltar a dormir nas ruas da cidade, mesmo em plena pandemia de Covid-19. Tal preocupação por parte da família warao, e as constantes referências ao hebu nas nossas conversas, levou-nos a considerá-lo como um elemento central nas suas interpretações dos fatos históricos e sociais, sendo fundamental para suas tomadas de decisão.

\section{Quando os hebu chegam ao Brasil: Doenças, práxis xamânica e (re)territorialização warao no Brasil}

Desde a primeira aparição do Covid-19 diante dos holofotes da mídia internacional, uma série de especulações e questionamentos a 
respeito da origem do vírus começou a emergir nos discursos de diferentes grupos sociais e representantes governamentais. Dos Estados Unidos partiu uma acusação de que a China teria criado o vírus em laboratório como medida de retaliação à economia do país rival ${ }^{38}$. Em contrapartida, a China acusou posteriormente o exército dos Estados Unidos de levar o vírus até Wuhan e disseminá-lo no país ${ }^{39}$. No início da pandemia, Rodolfo, atento às notícias, afirmou que a Covid-19 não era algo tão grave já que havia visto um médico na televisão afirmando isso. Dado o agravamento posterior da crise, no entanto, sua opinião mudou. Rodolfo e Florencia, assim como outros Warao, reelaboraram suas interpretações e pensamentos em torno da epidemia a partir do seu próprio saber ancorado na sua cosmologia e na sua história, bem como em suas experiências. O casal hoje considera o Coronavírus como um hebu zabana, um grande hebu, uma grande doença ${ }^{40}$.

A cosmologia warao está atrelada à importância da água e, particularmente, à dos rios no ambiente deltaico (AMODIO; RIVAS; DOX, 2006, p.11). Na mitologia warao encontramos uma divisão do seu território tradicional em quadrantes onde cada grupo warao exerce formas próprias de se relacionar com os recursos naturais correspondentes a cada região ${ }^{41}$. Os campos de ação dos hebu estão inseridos na distribuição dos quadrantes e se manifestam de acordo com as particularidades de seu quadrante específico através de um animal ${ }^{42}$. Os hebu são seres mitológicos responsáveis pelo surgimento de doenças visíveis e invisíveis. Conforme nos explica Florencia, os hebu são oriundos dos feitiços lançados pelos wisidatu, os quais ao mesmo tempo, possuem o poder de espantá-los. Segundo ela, a maneira mais eficaz de livrar-se de um hebu é expulsá-lo com a ajuda dos seguintes "doutores": um bajanarotu, um joarotu, ou um wisidatu ${ }^{43}$. Eles possuem o poder de cura e o conhecimento necessário para caçar esses espíritos e libertar as pessoas de suas tormentas. Rodolfo nos ensina a importância dos

$38 \quad$ Fonte: $<$ https://g1.globo.com/mundo/noticia/2020/05/06/o-laboratorio-chines-apontado-pelos-euacomo-local-de-origem-do-novo-coronavirus.ghtml>. Acesso em: 19/09/2020.

$39 \quad$ Fonte: $<$ https://oglobo.globo.com/mundo/porta-voz-da-china-sugere-que-militares-dos-eua-levaramcoronavirus-para-pais-24300774> . Acesso em: 19/09/2020.

${ }^{40}$ Em setembro de 2020, toda a família warao presente em Cuiabá ficou contaminada pela doença. Entretanto, os sintomas foram muito leves. Segundo Florencia, ainda que o teste de Covid-19 realizado tenha se mostrado "positivo", ela afirma que ninguém da sua família efetivamente "pegou o hebu" do Coronavírus.

${ }^{41} \mathrm{Na}$ tradição mitológica warao, cada quadrante se associa a um grupo e suas formas de exploração específicas, como os váquiros (caçadores de porcos selvagens), os horticultores, pescadores, coletores, etc. (GASSÓN; HEINEN, 2012, p. 49).

${ }^{42}$ As doenças são derivadas da ação dos hebu, que intervém na vida dos indivíduos. Os hebu mais poderosos se relacionam aos quatro pontos cardeais e com animais especiais: Warowaro (borboleta), Uraro (sapo), Domu Ariawara (Pássaro de origem) e Abajera (arara-vermelha). Cada animal produz sintomas de doenças diferentes, incluindo desde doenças respiratórias até disenteria. O conhecimento e a interpretação de cada wisidatu, bem como seu universo de referência, definirão outros hebu (AMODIO, RIVAS; DOX, 2006, p. 39).

${ }^{43}$ De todas as figuras xamânicas, o wisidatu é o mais poderoso, sendo o principal intermediário entre o mundo dos humanos e o dos espíritos, já que sua função vai além de curar as doenças, incluindo a de, por exemplo, dirigir os rituais de fertilidade. De fato, é quem remete os doentes aos outros especialistas, devido ao seu estreito contato com o mundo dos espíritos, estes lhes indicam através dos sonhos o tratamento a utilizar para cada doença e qual especialista pode tratar o enfermo (AMODIO; RIVAS; DOX, 2006, p. 41). MARÉCHAL, Clémentine; VELHO, Augusto Leal de Britto; RODRIGUES, Milena Weber; BUENO, Pietro. Transformações sociais e (re)territorialização Warao no Brasil: a trajetória de uma família frente à pandemia de covid-19. Espaço Ameríndio, Porto Alegre, v. 14, n. 2, p. 46-87, jul./dez. 2020. 
wisidatu: "o único que pode usar as maracas, com as quais se salvam as pessoas dos hebu, em seu ritual de cura". Quando o wisidatu e pai de Florencia faleceu, seu cunhado, o marido da sua irmã e aprendiz wisidatu, começou a receber visitas noturnas do espírito do seu sogro. Segundo Rodolfo, é necessário que o aprendiz fume bastante wina, um cigarro feito com as folhas da palmeira de açaí e tabaco, no intuito de estar preparado para receber o espírito do recém-falecido que lhe concederá tanto a legitimidade quanto os poderes necessários para seu cargo. É assim que, acolhendo o espírito do seu sogro, o cunhado de Florencia virou wisidatu, um dos poucos atuando no Brasil, segundo nossos interlocutores. Entretanto, ele faleceu no hospital de Manaus pouco tempo após a chegada de Florencia e Rodolfo no Brasil. Florencia nos explicou que o wisidatu foi a óbito após ter consumido uma comida preparada por uma mulher menstruada ${ }^{44}$. Segundo ela, o sangue da cozinheira atraiu o hebu que se alojou na comida, e ingerindo-a, o wisidatu passou a se contaminar pelo hebu que se manifestou durante sua hospitalização através de uma grave infecção urinária que, infelizmente, levou o homem à morte.

Os hebu que entram pela comida não contaminam só os wisidatu. São uma ameaça para toda a família, inclusive para as crianças. Em agosto de 2020, Florencia relatou que sua neta, Edimari, estava comendo muito pouco e em horários inadequados - "vovó! Vovó! Arroz! Arroz!", clamava a criança, mas, já havendo passado da meia-noite. Florencia explicou para a neta que ao cozinhar depois da meia-noite corria o risco de entrar um hebu pela comida. O seu marido incrementou que esse hebu geralmente faz com que a pessoa coma sem parar, mas sem nunca engordar.

Os hebu sedentos de sangue levaram também há dois meses, em maio de 2020, a sobrinha de Florencia que vivia nos caños. A jovem grávida teve um parto muito difícil e com acesso à pouca infraestrutura. Não havia energia elétrica, parteira e nem material hospitalar de suporte à parturiente e ao recém-nascido. Numa conversação telefônica, Florencia explicou que a jovem tinha sido "comida" por um espírito, atraído pelo sangue do parto ${ }^{45}$. A própria Florencia tem muitos relatos e também recordações sobre as medidas que os Warao devem tomar para evitar serem "pegos" por um hebu. Por exemplo, ela nos relata que não é recomendado que as mulheres tomem banho de noite e que devem evitar mexer na água e cozinhar enquanto elas estão menstruadas. Quando criança, Florencia foi possuída por um hebu que a fez gritar até que seu pai, um dos mais poderosos wisidatu, conseguisse expulsá-lo do corpo da filha.

Os hebu também se manifestam naquilo que os Warao categorizam como doenças dos criollos, disseminadas a partir de intervenções nos

\footnotetext{
${ }^{44}$ Florencia ressalta que os wisidatu não podem comer aliño e usar perfume. Devem permanecer o mais aberto possível para o contato com o mundo invisível. Amodio, Rivas e Dox (2006) também ressaltam o caráter perigoso do sangue menstrual para os Warao, algo que se reverbera em muitas outras sociedades indígenas (GOW, 1991; MCCALLUM, 1998). Para uma discussão mais profunda sobre pureza e perigo (DOUGLAS, 1991).

${ }^{45}$ Segundo Amodio, Rivas e Dox (2006), o sangue também atrai os nabarao, espíritos que vivem embaixo d'água e que podem assumir a forma do boto-cor-de-rosa e enfeitiçam os vivos, que deixam de comer. 
territórios tradicionais warao, e mais recentemente, também como parte de sua vinda ao Brasil. Assim, as tragédias que ocorrem, tanto na Venezuela quanto no Brasil, costumam ser interpretadas como decorrentes da atuação dos hebu. Tais intervenções parecem ter levado a novas formas de intervenção, aparições e significados dos hebu. Como ressalta Hill (1988, p.5), mito e história devem ser entendidos como "modos de consciência social através dos quais as pessoas constroem marcos interpretativos compartilhados ${ }^{46}$ ". Os mitos, assim como a história, são linguagens através das quais as populações manifestam sua interpretação dos acontecimentos e produzem subjetividades. Dessa maneira, os hebu presentes nas narrativas dos Warao também dizem respeito aos processos históricos que atravessaram e das condições de vida difíceis nas quais se encontram. Assim, as tragédias que ocorrem, tanto na Venezuela quanto no Brasil, costumam ser interpretadas como decorrente da atuação dos hebu. Em meio a um processo de migração forçada, carregado de esperança, mas também de dor, morte, sofrimento, miséria e saudade, os hebu seguem intervindo em suas trajetórias como ferramenta explicativa dos fatos sociais e base epistemológica de conhecimento.

Sendo assim, no contexto migratório, os hebu são também um meio de comunicação entre as famílias warao que, mesmo distanciadas fisicamente, se reconhecem nas interpretações dos dramas sociais compartilhando os seus significados em base à mitologia e a uma práxis xamânica que se adapta a novos contextos (GROISMAN, 1996; MARÉCHAL, 2019). Os wisidatu passam assim a atuar em situações totalmente diferentes, tendo, por exemplo, que atender as pessoas por Whatsapp. Dessa maneira, os hebu já não se manifestam apenas nas águas do Orinoco, na forma de animais específicos; inclusive, podem intervir até para explicar lesões no futebol. Desde sua passagem por Porto Alegre, Rodolfo acompanha atentamente pelo celular os jogos do Sport Club Internacional. Chamou a nossa atenção em uma conversa telefônica para a recente lesão do centroavante Paolo Guerrero, a explicação do nosso interlocutor: "viram que Guerrero está com hebu?"

Como apontamos na introdução, a mobilidade warao deve ser entendida também como ação política. Constitui-se como uma forma de resistência e uma manifestação da autonomia e protagonismo dessa população diante das "crises" políticas e econômicas que os assolam. Desse modo, não é surpreendente ouvir de nossa interlocutora Florencia que: "Warao é feito para caminhar, não é feito para ficar trancado, ou ficar só num lugar". Da mesma maneira, a aparição dos hebu sob outras formas e em outras águas, por exemplo, nas do ralo do banheiro na cidade, é testemunha também desse protagonismo. A mobilidade expande assim o território warao para além das fronteiras nacionais, e a presença dos hebu e dos wisidatu no Brasil deve ser considerada como manifestação de um novo processo de reterritorialização (BARBOSA, 2007) entre os integrantes dos grupos.

\footnotetext{
46 Tradução dos autores.

MARÉCHAL, Clémentine; VELHO, Augusto Leal de Britto; RODRIGUES, Milena Weber; BUENO, Pietro. Transformações sociais e (re)territorialização Warao no Brasil: a trajetória de uma família frente à pandemia de covid-19. Espaço Ameríndio, Porto Alegre, v. 14, n. 2, p. 46-87, jul./dez. 2020.
} 
As condições materiais às quais devem se adaptar os Warao se articulam com os marcos interpretativos enraizados na mitologia, de modo que onde há pouca chance de diálogo e pouca possibilidade de que suas demandas sejam ouvidas, os hebu tendem a aparecer. Entretanto, embora essas dimensões se articulem, os Warao não deixam de denunciar a falta de comida, medicamento ou o excesso de controle de parte dos administradores dos alojamentos, albergues ou casas de acolhida ${ }^{47}$. As situações de instabilidade junto com a falta de acesso a serviços básicos aparecem de maneira exemplar quando Florencia relata que em Cuiabá um dia acordou sem poder andar ou falar, tendo sido pega por um hebu que vagava nos arredores. Nesse caso específico, sua saúde dependia não somente do desaparecimento do hebu que assombrava a casa, mas também de acompanhamento médico. Por isso, auxiliamos remotamente tanto no seu deslocamento, quanto na comunicação com profissionais da saúde, até que recebesse o atendimento necessário, o que foi um processo na sua totalidade extremamente difícil e confuso, conforme será relatado posteriormente.

Efetivamente, a inexistência de uma assistência em saúde especializada para o atendimento dos indígenas migrantes tem tido deploráveis consequências para essa população, como já apontamos. Em Cuiabá, a mãe de Jesus apresentou problemas renais logo após o começo da pandemia de Covid-19. A mulher idosa tem uma pedra no rim que precisa ser retirada por meio cirúrgico, intervenção que Ihe foi negada em decorrência da pandemia, e nenhuma atenção especial foi dada à senhora que teve que ser levada com urgência ao hospital. Para isso, devido à falta de atendimento dos órgãos competentes, tivemos que ligar de nosso celular para um motorista de aplicativo que iria em Cuiabá buscá-la na sua casa e levá-la até o hospital. Um evento parecido aconteceu com Florencia, que sofre com problemas de pressão e por isso precisa fazer uso contínuo de Losartana. Em Porto Alegre, foi auxiliada a obter o medicamento. Porém, ficou sem ao retornar a Cuiabá onde esteve muito doente por vários dias. Tentamos contato várias vezes com pessoas da SESAI, inclusive um dos funcionários da instituição chegou a nos responder via Whatsapp que esta: "só se encarrega dos indígenas brasileiros do Mato Grosso". Somente alguns dias mais tarde, após encontrarmos um novo contato, tivemos o pedido de ajuda reencaminhado, coincidentemente, para uma policlínica do SUS que tinha se recusado a atender Florencia anteriormente sob argumentos do tipo "estamos sem médico", ou "aqui só estamos atendendo pacientes com suspeita de Covid-19".

Embora exista aceitação da medicina ocidental pelos Warao, os mal-estares de ordem física ou psíquica interpretados como doença de hotarao tendem a recorrer à dimensão cosmológica para interpretar e categorizar as enfermidades, em "tipos" de hebu e atribuir as causas à bruxaria ou mau-olhado. As doenças acabam adquirindo de forma direta

\footnotetext{
${ }^{47}$ Foram diversas as situações nas quais a família warao mostrou indignação em relação às imposições dos integrantes da Associação em Cuiabá. Seja por chegar muito cedo na casa, seja por impor uma rotina de organização e limpeza da casa que não corresponde à dinâmica warao. Também, eles manifestaram seu incômodo em relação à indicação de uma só pessoa como "encarregado" do grupo familiar. 
ou indireta um sentido no universo cosmológico warao, capaz de produzir um conjunto de saberes espirituais e materiais destinados à sua resolução (AMODIO; RIVAS; DOX, 2006, p. 37). Em um dos pareceres, por exemplo, os Warao "manifestaram o desejo de que os líderes e xamãs warao [wisidatus] acompanhassem os tratamentos prescritos pelos médicos, levando em consideração suas práticas tradicionais de cura" (MOUTINHO, 2017, p. 36).

Imagem 2- Paulino Zapata, wisidatu e cunhado de Rodolfo.

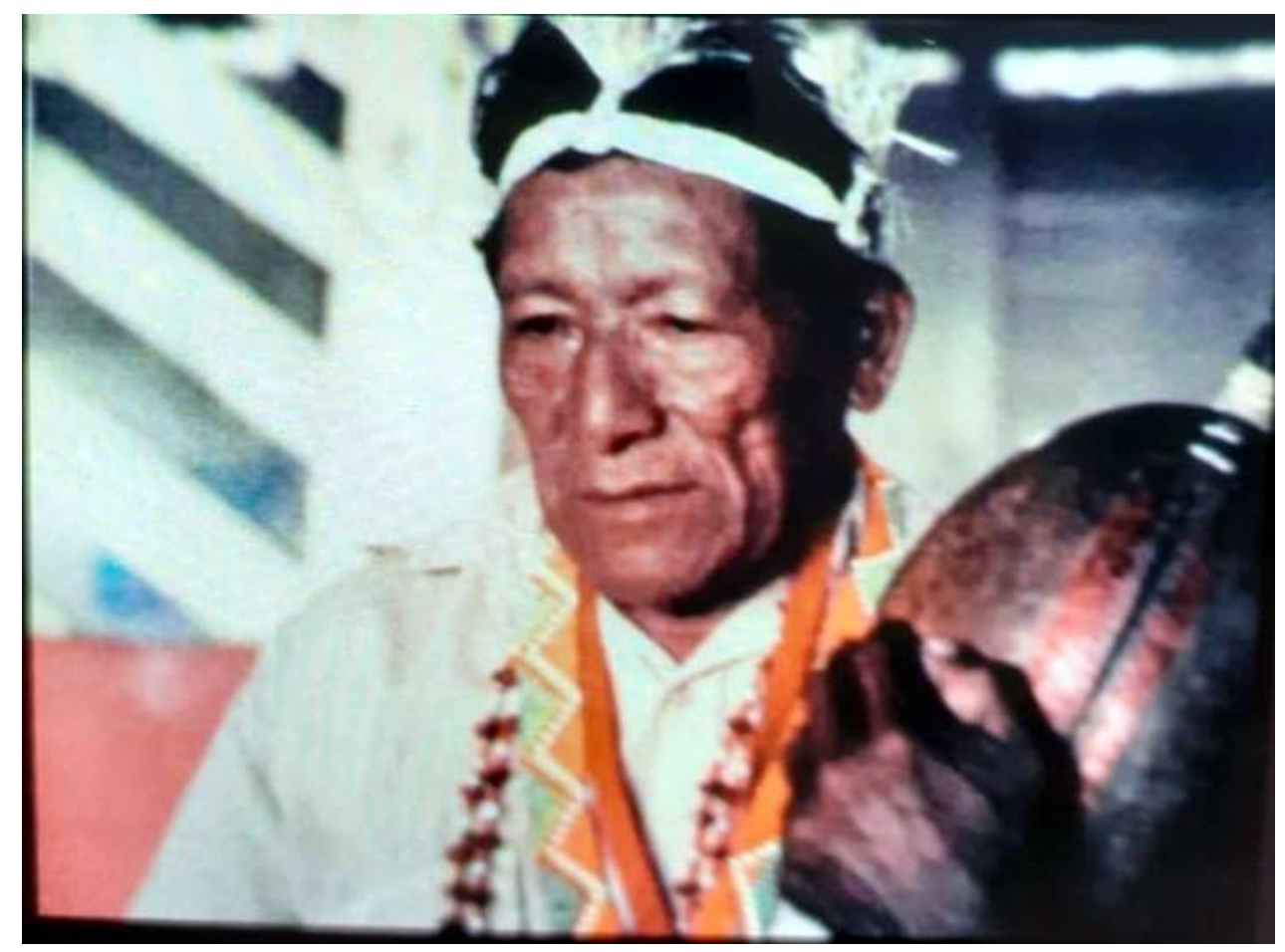

Fonte: Fotografia entregue aos autores, tirada no Brasil durante o ano de 2019. Autor desconhecido.

A presença dos hebu, para além das águas do delta e a partir de novas vivências trágicas, é tão significativa que muitas famílias warao deixam seus abrigos em busca de outro lugar para viver, até mesmo na rua se for preciso, caso o abrigo esteja habitado por um perigoso hebu. Moutinho $(2017$, p.13) registra o caso de uma família que deixou o abrigo após a morte de um de seus parentes em decorrência da presença de um hebu:

A partir do dia 15 de abril, o grupo de indígenas que estava na casa 3 foi realocado para uma quarta casa (casa 4) após o falecimento do indígena Américo Mendonza, pois seus familiares alegaram que havia espíritos habitando o quarto onde estavam.

No caso que mencionamos anteriormente, durante os primeiros dias do retorno de Florencia e Rodolfo em Cuiabá, todos estavam a ponto de devolver a casa aos seus "encarregados", o pessoal da Associação de 
Amparo à Família Carente. As ligações de telefone e os relatos que recebemos por mensagem transmitiam a preocupação que essa aparição do hebu evocou, tanto para Florencia em Porto Alegre que projetava seu próximo encontro com a família, como entre os moradores da casa que se manifestavam prontos a saírem da moradia ${ }^{48}$. Nos dias anteriores e durante o trajeto entre Porto Alegre e Cuiabá, a situação se intensificou: relatos chegavam de que estavam organizando seus pertences para sair da casa. Ao mesmo tempo em que os relatos apontavam à presença preocupante desse hebu que aparecia todas as noites no banheiro, nossos interlocutores também deixavam entrever que a situação material e emocional na casa os inquietava. Não havia suficiente comida e, devido ao coronavírus, os "encarregados" recomendavam fortemente que ficassem trancafiados dentro de casa. Esta situação Ihes impossibilitava conseguir seu próprio dinheiro, tornando-os assim ainda mais dependentes. A chegada de Florencia, no entanto, foi alegre. Cercada de seus familiares, começou logo a trabalhar em resolver os problemas, já que, além de importante figura política ${ }^{49}$ dentro da família, ela é filha de wisidatu. Graças ao seu trabalho, o hebu rapidamente recuou, mostrandose menos ameaçador que os dias anteriores, e, além disso, após estudar o caso, Florencia afirmou que se tratava de um "hebu pequeno". A tensão relacionada ao hebu foi se amenizando na casa familiar conforme alguns acontecimentos deram um pouco de sossego à família: primeiro, a chegada de Florencia, Rodolfo e Edimari com alimento e agasalhos para todos; entregas semanais e gratuitas de frango e ovos diretamente em sua casa, que Florencia arranjou; e a primeira parcela do Auxílio Emergencial para a maioria dos membros da família.

Assim, problemas cotidianos que se acumulam, como a necessidade de comida ou de liberdade, parecem chamar os hebu ao mesmo tempo em que estes podem ser os responsáveis por provocar ou piorar essas situações. Dessa maneira, as aparições dos hebu podem ser lidas também como uma alerta de perigo, como uma expressão - desde os modos de linguagem interpretativos e explicativos dos Warao - do descaso ou da falta de entendimento de parte das instituições brasileiras em relação a essa população. Na medida em que os problemas são remediados ou encontram uma solução, os hebu se afastam. Dessa maneira, para espantar os hebu, os Warao apelam tanto aos métodos tradicionais - o wisidatu e seus poderes, quanto à busca de apoio material com os não indígenas como comida, acesso a medicamento, roupa ou a possibilidade de sair para a rua. As duas linguagens são utilizadas em referência a um mesmo processo histórico e seus impactos, e, embora as

\footnotetext{
${ }^{48}$ Um dado interessante é que os vizinhos dos Warao confirmaram que a casa estava habitada por "espíritos ruins", isso porque, segundo eles, um dos antigos moradores era um usuário de drogas que teria deixado a casa com "más energias".

${ }^{49}$ Em base à uxorilocalidade warao assim como a partir da nossa experiência etnográfica, podemos afirmar que Florencia é uma figura política matriarcal na família. Acolhe com ela os seus genros e, na mudança para o Brasil, também a nora. As tomadas de decisões do grupo são geralmente realizadas por ela, sobretudo no que diz respeito à saída para vender artesanato ou às viagens para outras cidades. Algumas instituições ou entidades que assistem a família, como a Associação, não a enxergam dessa forma, transferindo para seu genro, Jesus, um homem quase trilingue (warao, espanhol e portuguẽs) o rol de liderança políticafamiliar, o que por vezes gera conflitos tanto entre os Warao quanto entre os Warao e os "encarregados". 
responsabilidades não sejam necessariamente atribuídas aos mesmos atores, as situações vividas, conforme tentamos demonstrar, relacionamse.

É preciso assim entender como as dificuldades cotidianas dos Warao migrantes no Brasil os tem forçado a elaborar novas estratégias de reprodução da vida e certa adaptação em relação aos cuidados relacionados à saúde, sobretudo no contexto atual de pandemia. A inserção em um modelo diferente de saúde pública e a relação de dependência desencadeada pelo contexto migratório provoca desentendimentos com os atores que os Warao identificam como "seus encarregados". A bajuka, saúde, para os Warao, não necessariamente corresponde aos mesmos parâmetros que os profissionais com quem devem lidar possuem. Por exemplo, para os Warao, evitar sair nas ruas ou colocar uma máscara, em nada ia possibilitá-los escapar do hebu zabana provocado pelo Covid-19. Ao contrário, segundo Florencia, é "ficando presos em casa" que os Warao poderiam ficar doentes.

Além disso, o problema da documentação também limita o acesso a certos serviços. Florencia, que ainda não possui CPF, fica excluída de alguns direitos (o mais importante sendo o Auxílio Emergencial) e depende assim da flexibilização de normas por parte de funcionários ${ }^{50}$. Ao mesmo tempo em que o contato dos Warao com o poder público ou com diversos setores da sociedade brasileira tem assegurado sua sobrevivência em relação às condições básicas de existência como uma casa, comida e documentos, tem também provocado uma série de questionamentos da parte desses grupos familiares em relação às porosas fronteiras entre tutela e autonomia. A chegada da sobrinha de Florencia com suas filhas e netos à Cuiabá desencadeou desentendimentos entre a Associação e a matriarca da família. Na perspectiva dos Warao, a casa onde vivem agora é grande e espaçosa suficiente para abrigar seus familiares. Porém, a Associação optou por não acolher mais pessoas na casa, justificando a decisão pela falta de capacidade de atendimento e por medidas de segurança. Esta determinação decepcionou profundamente Florencia, que se viu na obrigação de fechar as portas a sua sobrinha, algo que fere os valores dessa família warao, enraizados no que chamamos de mesa estendida e anteriormente desenhado como demand sharing (GARCÍA-CASTRO, 2018), segundo os quais, aquele que tem deve compartilhar com os outros. Florencia não se deu por vencida ao ter de "fechar a porta" para os seus parentes, e viu-se impelida a "abrir a janela". Determinada em auxiliar sua sobrinha, entrou rapidamente em contato com o dono de uma casa vizinha à sua e, após negociações, conseguiu um aluguel de $\mathrm{R} \$ 600$ para alojar sua família recém-chegada a Cuiabá. Além disso, arrumou a casa com móveis que Ihe sobravam e com utensílios básicos e contribui,

\footnotetext{
${ }^{50} \mathrm{Em}$ setembro de 2020, quando foi levada para fazer um exame de sangue em função do seu diagnóstico de Covid-19, foi barrada por não ter CPF, impedida de realizar o exame. Finalmente, Florencia conseguiu realizar o exame porque contou com a ajuda de um servidor público que resolveu usar do seu poder para ajudá-la no processo. Esse pequeno exemplo aponta, porém, a situação de subalternidade na qual se encontram os Warao indocumentados no Brasil. Sem a boa vontade do policial, Florencia não teria sido atendida pela instituição pública mesmo apresentando uma suspeita de Covid-19.
} 
quando possível, com dinheiro e comida, viabilizando, assim, a permanência da família de sua sobrinha em Cuiabá e fortalecendo, por conseguinte, a presença warao na cidade.

A Associação se comprometeu em ajudar os Warao a encontrarem trabalho para que estes possam pagar seus próprios custos de aluguel e comida até o 31 de dezembro, dia em que encerra o contrato e o apoio logístico da entidade. Durante uma reunião com membros da Associação, questionamos sobre essa demanda, oriunda principalmente dos homens warao. A única opção apresentada foi o trabalho noturno em frigoríficos da região, sendo esses locais, em vários lugares do mundo, e principalmente no Brasil, uns dos maiores vetores de contaminação de Covid-19. Diante da falta de emprego formal, os Warao costumam ser contratados como diaristas em obras de construção ou para trabalhos pontuais, por um salário diário inferior a $\mathrm{R} \$ 50$. As mulheres, entretanto, seja através da confecção e comercialização do seu artesanato, seja através do ebú quitane - a prática de "pedir/exigir moeda na rua" constituem-se como as principais provedoras de renda da sua família.

\section{Do tear às ruas: Desafios e relações de trabalho em contexto migratório}

Em meio ao cenário no qual se encontra a família de Florencia e Rodolfo, surgem novas práticas e estratégias que auxiliam na sobrevivência e na reprodução material do grupo. Ao longo da nossa convivência - mais virtual do que física - identificamos três principais formas de articulação do trabalho no contexto migratório da família de Florencia e Rodolfo: a prática do ebú quitane, o trabalho informal como diarista e a fabricação e comercialização de artesanato. Cada uma dessas atividades contém suas devidas particularidades, que dependem do contexto e da situação em que os Warao se encontram. No entanto, apesar de suas diferenças, essas três formas de organização do trabalho ressaltam as múltiplas formas de agência warao frente a um contexto marcado por diversos tipos de violência (ROSA, 2020).

Sendo já exaustivamente tratada por diversos antropólogos (AYALA, LAFÉE-WILBERT; WILBERT, 2008; GARCÍA-CASTRO, 2000; GASSÓN; HEINEN, 2012; ROSA, 2020), a prática de pedir o dinheiro nas ruas ocorre de maneira sistemática desde a década de 1990, constituindose como um dos principais meios pelos quais os Warao que estão em situação de migração obtêm os recursos necessários para sobrevivência do grupo. Essa atividade, realizada principalmente pelas mulheres, é o principal exemplo da maneira em que as formas de organização tradicional warao são trazidas para dentro do contexto urbano. Segundo Garcia-Castro (2018, p.36), o ato de "pedir na rua" é atravessado pelo princípio de reciprocidade warao caracterizado como "pedir a quem sobra" ou "demand sharing". Este é definido como umas das normas de subsistência e reciprocidade praticada entre os membros de uma mesma comunidade quando alguém carece de um recurso que outro possui em abundância. 
Esse princípio dialoga com o que definimos anteriormente como mesa estendida e, como vimos, parece se expressar na comensalidade. Isso fica evidente de diversas formas nas conversas que temos por telefone com Florencia, quando ela demonstra sua preocupação em enviar alimentos e dinheiro para seus parentes que ficaram na Venezuela. Em relação a essa preocupação, ocorreu um episódio curioso em Cuiabá, quando a acumulação de alimentos na casa - para, quando surgisse uma oportunidade, os Warao enviarem para Venezuela - se converteu em um problema para a Associação "responsável" por eles. Os representantes da entidade argumentaram que não se podia estocar alimentos daquela maneira pois, segundo eles, a maioria estava estragado ou prestes a estragar e deveriam ser descartados. Em contrapartida, Florencia e sua família não conseguiam aceitar que teriam que jogar alimentos fora ao mesmo tempo em que sua família passava fome na Venezuela. Ainda mais que, mesmo em períodos de dificuldade, Florencia sempre que podia compartilhava com o restante de sua família: "Tenho muita família, e na Venezuela parte de minha família passava fome, passava fome, fome, e as crianças chegavam na minha casa para pedir comida, se eu tinha eu entregava, mas se eu não tinha nada eu não entregava", nos comenta em uma conversa por telefone em agosto de 2020.

Portanto, longe dos princípios de acumulação característicos do pensamento ocidentalista ${ }^{51}$, na visão dos Warao a maior abundância de alimentos e recursos em um determinado centro urbano justifica a sua divisão (GARCÍA CASTRO, 2018, p.36.; AYALA LAFÉE-WILBERT e WILBERT, 2008 , p.101). Por isso, a atividade não é vista de maneira alguma como pejorativa ou degradante pelos indígenas que consideram que as pessoas que possuem comida e recursos têm o dever de distribuí-los. Portanto, para os Warao, as pessoas que recusam oferecer sua solidariedade são consideradas como mesquinhas e chamadas de wani ou koi. É dessa maneira, muito comum, que os Warao ficam indignados com a pouca solidariedade dos não indígenas ${ }^{52}$. Assim, a atividade chamada em warao de ebú quitane, que muitas vezes é acompanhada de cânticos warao realizados pelas mulheres, constitui-se como uma alternativa a uma subsistência difícil no território habitado e/ou percorrido - tanto é que, na Venezuela, as viagens para arrecadar dinheiro eram extremamente bem organizadas (AYALA LAFÉE-WILBERT e WILBERT, 2008, p.101).

No entanto, a sociedade civil não vê essa atividade com os mesmos olhos, enxergando os Warao que pedem na rua como "oportunistas" e "vagabundos", ou ainda considerando que "sujam" a cidade pela sua existência. A presença de crianças, sem dúvida, aumenta a tensão entre os órgãos do governo e os Warao, acarretando, em diversas ocasiões, a atuação do Conselho Tutelar (MOUTINHO, 2017, p.37). É efetivamente muito raro ver uma mulher warao na rua sem uma criança, inclusive nas cidades venezuelanas. Ayala Lafée-Wilbert e Wilbert (2008, p.103) registraram testemunhos de algumas mulheres warao que afirmaram

\footnotetext{
${ }^{51}$ Sobre Ocidentalismo ver o belo texto de Fernando Coronil (1999).

52 Não podemos esquecer, portanto, dos impactos subjetivos das relações de dominação. Como ressalta Quijano (2005), o colonizado aprende a se ver com o olhar do colonizador, incorporando, assim, sentimentos de inferioridade e vergonha do seu modo de vida, sentir e pensar. 
fazer mais dinheiro quando acompanhadas de crianças e, por isso, elas criaram certas estratégias com o objetivo de otimizar as saídas. Dentre elas podemos destacar o cuidado coletivo de crianças entre uma mesma rede de parentesco, de modo que mesmo as mulheres que não têm filhos pequenos possam sair acompanhadas por algum neto ou sobrinho (AYALA LAFÉE-WILBERT e WILBERT, 2008. ROSA, 2020). Porém, a presença de crianças também se justifica pela necessidade de cuidado, uma vez que a grande maioria delas se encontra em fase de amamentação (MOUTINHO, 2017, p.22) e porque, como para muitas sociedades indígenas, entre os Warao, o processo educativo e os aprendizados se atrela a uma convivência e às andanças junto das mães no dia a dia. Assim, o acompanhamento dos pais nas suas atividades cotidianas constitui-se como parte indissociável do aprendizado sociocultural das funções políticas e pedagógicas e do desenvolvimento infantil (OLIVEIRA, 2012, p. 172). Segundo o professor de Direitos Humanos, Assis da Costa Oliveira (2012), a presença das crianças indígenas junto dos pais nas suas atividades laborais cotidianas promove a sociabilidade delas com outras crianças e adultos, e, através disso, são orientadas a desenvolver conhecimentos e habilidades que as transformam em participantes ativos da comunidade, adquirindo a capacidade de cumprir responsabilidades, e inserir-se na divisão sexual do trabalho. Edimari, de 4 anos, por exemplo, ainda é muito pequena para aprender a fazer artesanato, mas acompanha a avó nas vendas. Florencia pretende ensiná-la a fazer pulseiras e colares quando estiver um pouco maior, aos 6 anos de idade, "aí ela assiste, vê como faz, e aprende", diz a avó. Ela, que começou a fazer redes com palma de oji aos 8 anos de idade, aprendeu a fazer artesanato em miçangas somente anos mais tarde, com a cunhada. Estando em Cuiabá, as pedras de miçanga são definitivamente mais acessíveis que a palma de oji. Assim, Edimari aprenderá primeiro a tecer com elas, e mais adiante quando for possível, com as fibras da palmeira.

Os laços de parentesco devem ser entendidos como os principais meios de organização das migrações (ROSA, 2020, p. 268). Assim, nesse processo de aprendizagem inscreve-se, também, a profunda relação entre parentesco e mobilidade. As crianças se adaptam a novas situações afinando laços com primas, irmãs e tias, que são imprescindíveis em um cenário às vezes muito adverso como é o da migração. Elas aprendem, assim, a conviver com mulheres que não são necessariamente suas mães na eventualidade de ter que ficar separadas delas por um longo período ou de forma definitiva, conforme pode acontecer nesses contextos adversos.

Nas ruas das grandes cidades, as mulheres e crianças warao estão expostas ao perigo e à violência que emana da sociedade e dos criollos. Não são raros os relatos de brasileiros tentando comprar crianças warao de suas mães, possivelmente no intuito de torná-las servas ou escravas ${ }^{53}$. Florencia, por exemplo, nos relatou um episódio que ocorreu em Porto Alegre, em que um brasileiro, após dar muito dinheiro e alimento para

\footnotetext{
${ }^{53}$ Em um artigo de junho de 2004, a Folha de São Paulo apresenta o alarmante dado de 559 mil crianças em situação de servidão ou semiescravidão no Brasil. Fonte: $<$ https://www1.folha.uol.com.br/fsp/mundo/ft1106200416.htm>. Acesso em: 19/09/2020. 
ela e sua neta, convidou as duas para entrarem no carro e irem com ele sob a promessa de que "daria mais coisas". Florencia recusou o convite, pois já tinha escutado histórias parecidas que ocorreram com outros Warao, além de considerar que "não se pode confiar nos criollos". Aqui fica evidente a importância das redes de comunicação entre os Warao que estão no Brasil e que, ancoradas no parentesco, possibilitam a troca de informação com o intuito de cuidarem uns dos outros (ROSA, 2020, p.35).

Apesar dos riscos inerentes a essa atividade, ela acaba muitas vezes se tornando a única opção viável para os Warao adquirirem os recursos necessários para sua subsistência nos centros urbanos. Em todo caso, ebú quitane, constitui-se como a atividade que dá o melhor retorno financeiro. Florencia nos comenta que, mesmo durante a pandemia, ela consegue obter ao redor de $\mathrm{R} \$ 120$ por dia pedindo e cantando no semáforo enquanto seu marido, Rodolfo, trabalhando como diarista na limpeza, ganhava em torno de $\mathrm{R} \$ 50$ por dia. Como já relatamos, uma outra fonte de renda para os Warao é o trabalho informal como diarista, praticado principalmente pelos homens.

Quando aborda a exploração da força de trabalho warao na Venezuela, Garcia-Castro (2018, p. 41) afirma que os Warao são uma "verdadeira classe proletária indígena", baseada em critérios étnicos ${ }^{54}$. No Brasil, esse processo se intensifica, já que a própria condição do imigrante favorece a exploração. Como afirmam vários autores (MARX, 2013; MEILLASSOUX, 1975; SAYAD, 1998), os migrantes estão geralmente dispostos a aceitar condições de trabalho que uma pessoa natural do país e já inserida no mercado de trabalho não aceitaria. A condição de indígena migrante, à qual estão associados os Warao, torna-os, assim, duplamente subalternizados (ROSA, 2020) e isso se expressa notadamente nas relações capital/trabalho das quais eles participam. Por exemplo, Rodolfo só encontrou um trabalho oito meses após ter chegado no Brasil, quando um policial de Cuiabá o contratou para realizar um serviço de limpeza, totalmente informal, da pista de tiro de uma sede da Brigada Militar. Trabalhou em torno de um mês e recebia menos de $\mathrm{R} \$ 50$ por dia sem nenhum benefício, direito ou sequer com horário fixo: "quando eu terminava de limpar, acabava o trabalho", comenta. A situação não foi diferente com Jesus, seu genro. Este era chamado "de vez em quando" para trabalhar na limpeza de um restaurante em Itacoatiara (AM), recebendo $\mathrm{R} \$ 40$ por dia de trabalho. Em Cuiabá, os homens warao trabalharam como ajudantes de pedreiro, recebendo em torno de $R \$ 50$ por dia cada um, mas após alguns dias de serviço foram avisados pelo patrão de que "não havia mais trabalho".

Através desses pequenos exemplos podemos perceber que, por um lado, o trabalho fornecido pelos Warao caracteriza-se pela ausência de qualquer tipo de mecanismo legal de regulação trabalhista, já que em nenhum dos casos citados houve contrato assinado - apenas acordos orais com os patrões. Essa prática é um lugar-comum quando se trata de trabalho indígena, uma vez que, como ressalta João Pacheco de Oliveira (2016, p. 25), estes historicamente "foram mobilizados não por contratos

\footnotetext{
${ }^{54}$ Ver também Quijano (2005) para uma abordagem mais sistemático sobre estruturação da sociedade moderna. 
e salários, mas por vínculos pessoais, acordos e parcerias, raramente escritos e facilmente manipuláveis". Ademais, a instabilidade do emprego e a condição servil à qual são submetidos os Warao, intensifica a subalternização. Além de demorarem meses para encontrar um trabalho e serem chamados só quando convém aos empregadores, ainda podem ser dispensados a qualquer momento, já que os Warao não têm à disposição os respaldos legais para se defenderem. Ainda se adiciona a isso a dificuldade para se comunicarem em português, o que os torna mais vulneráveis, sujeitos a armadilhas e enganos dos patrões.

Um dos modelos específicos de exploração, segundo o antropólogo Claude Meillassoux (1975), é baseado na articulação entre um "duplo mercado de trabalho" e uma rotação de mão de obra rural, duas políticas sustentadas por uma ideologia racista. Para o autor, o duplo mercado é caracterizado por uma divisão dos trabalhadores em duas categorias: os trabalhadores integrados e estáveis que se reproduzem integralmente no setor capitalista, e a dos trabalhadores migrantes que somente se reproduzem nele parcialmente. No caso dos Warao, como vimos, eles não dependem exclusivamente do setor capitalista para se reproduzirem socialmente, já que a fabricação de artesanato e a prática do ebú quitane complementam o trabalho assalariado informal. Isso atrai o capitalismo, pois, nessa condição, os trabalhadores migrantes ou imigrados são mais facilmente exploráveis. Por um lado, a instabilidade do trabalho temporário dificulta a sua integração junto dos trabalhadores nacionais, o que diminui as possibilidades de criação de uma consciência de classe entre esses trabalhadores. Por outro, por receio de serem expulsos do país que os acolhe ou por medo de perder o status legal de refugiado, os trabalhadores imigrados, mesmo em condição de superexploração ou servidão, preferem não denunciar os abusos laborais e evitam se organizar politicamente para conquistar seus direitos.

Os Warao, enquanto migrantes e indígenas, são considerados como mão de obra barata não qualificada - mesmo que estes tenham tido, no seu país de origem, uma formação em culinária ou experiência de docência -, facilmente manipulável e explorável. Atrelado à ideologia racista, o duplo mercado de trabalho expressa-se como uma materialização da colonialidade do poder e do capitalismo sob os Warao, enquanto indígenas estrangeiros, correm o perigo de constituir-se, em um futuro próximo, numa nova classe de trabalhadores superexplorados, substituindo, nos frigoríficos do Brasil, os indígenas brasileiros, que há um tempo se organizam interpelando o MPF e buscando o apoio de sindicatos para evidenciar e denunciar a violência laboral e as condições de trabalho degradantes às quais estão submetidos nesses espaços ${ }^{55}$.

Além disso, por enquanto a única proposta de trabalho assalariado que os Warao receberam em Cuiabá foi mediada por uma das suas

\footnotetext{
${ }^{55}$ No Rio Grande do Sul, a força de trabalho kaingang nos frigoríficos está sendo trocada pela venezuelana. Em 13 de fevereiro de 2020, a JBS/Seara de Chapecó (SC) recebeu 68 venezuelanos que foram contratados para trabalhar nas linhas de produção. Desde 2018, a Seara contratou no total mais de 600 venezuelanos nas suas fábricas no MS e em SC. Fonte: <https://mpt.jusbrasil.com.br/noticias/100032726/caciquesdenunciam-irregularidades-em-frigorificos-de-santa-catarina $>$. Acesso em: 02/09/2020. 
"encarregadas" e secretária da Associação ${ }^{56}$ e não chegou a ser concretizada, pois os Warao não possuem ainda carteira de trabalho. Assim, é, sobretudo através da força de trabalho das mulheres, que a economia warao se reproduz no contexto migratório aqui abordado. Além da atividade de pedir/exigir dinheiro nas ruas e nos semáforos, as mulheres - e em certa medida também os homens - confeccionam artesanatos.

Já tendo um certo destaque desde os deslocamentos entre centros urbanos venezuelanos (AYALA LAFÉE-WILBERT e WILBERT, 2008), a fabricação e comercialização de artesanato figura como uma das formas de articulação do trabalho mais interessantes de serem analisadas no contexto migratório, principalmente pela criatividade e a inventividade que os Warao desenvolvem neste processo de reelaboração da sua cultura. Florencia aprendeu com sua mãe, ainda quando criança, a confecção de artesanato usando a fibra de oji:

Aprendi porque minha mãe estava fazendo, minha mãe estava fazendo e eu estava sentada na volta dela, ela estava fazendo e eu estava olhando. Como minha mãe estava fazendo isso, vou aprender quando for grande, aprender o que estava fazendo minha mãe. Estava pensando assim, por isso aprendi assim (Florencia Quevedo, agosto de 2020).

Este conhecimento foi de extrema importância para a nossa interlocutora que conseguia, através da venda ou troca do artesanato que produzia, adquirir dinheiro e alimentos para ajudar sua família. Muitas vezes, inclusive, Florencia chegava a realizar uma dupla jornada de trabalho. Como ela mesma nos conta, passava a manhã inteira cozinhando na escola onde trabalhava e relata que: "quando chegava em casa eu trabalhava com oji". Essa renda adicional complementava o sustento da família, que na época era composta por salários de 400 bolívares (221 reais) cada um, sendo Rodolfo trabalhava pela prefeitura de Barrancas limpando calçadas.

Quando chegaram no Brasil, a dificuldade em conseguir os materiais necessários para a confecção de artesanato paralisou temporariamente a produção. É interessante destacar que essa dificuldade na obtenção de matéria-prima, principalmente a fibra de oji, não é exclusiva da família de Florencia, tendo afetado diversos outros grupos familiares warao, sobretudo desde o início da pandemia quando as fronteiras entre Venezuela e Brasil foram fechadas. Anteriormente, os Warao buscavam a fibra de oji na Venezuela e voltavam ao Brasil para confeccionar e vendê-lo (MOUTINHO, 2017, p.18). Hoje, a obtenção da palma de oji fora do Brasil é impossível, o que condiciona os Warao a usarem outros materiais para a confecção do seu $\operatorname{artesanato~}^{57}$ e a

\footnotetext{
${ }^{56}$ A questão da mediação da Associação nas relações sociais de trabalho dos Warao enseja um tema de pesquisa muito interessante e esperamos que possa ser aprofundado em estudos futuros.

${ }^{57}$ Mesmo assim, Florencia relata que conseguiu levar para Cuiabá material suficiente para a fabricação de doze cestas de oji. 
reelaborarem suas práticas culturais. Quando questionada com quais materiais fabrica suas peças, Florencia respondeu com outra pergunta: "aqui ou na Venezuela?" O uso de miçanga, por exemplo, possibilita a Florencia a reprodução do trabalho que realiza desde criança, mesmo encontrando-se tão distante dos caños. Recebemos todas as semanas diversas fotos enviadas por Florencia que, orgulhosa, nos mostra suas novas criações. Além disso, Rodolfo conta sobre como tem ajudado sua esposa na confecção das novas peças, mesmo admitindo que precisaria: "fazer um curso para fazer bem". A incorporação dos homens na confecção do artesanato warao é significativa das mudanças e das estratégias de adaptação a novos contextos que os Warao tecem nas suas andanças pelo Brasil. Sem opção de trabalho assalariado, os homens se associam às mulheres nas suas diversas atividades, seja para pedir/exigir dinheiro nas ruas, seja para a realização de artesanatos.

Imagem 3 - Florencia Quevedo confeccionando artesanato no seu tear.

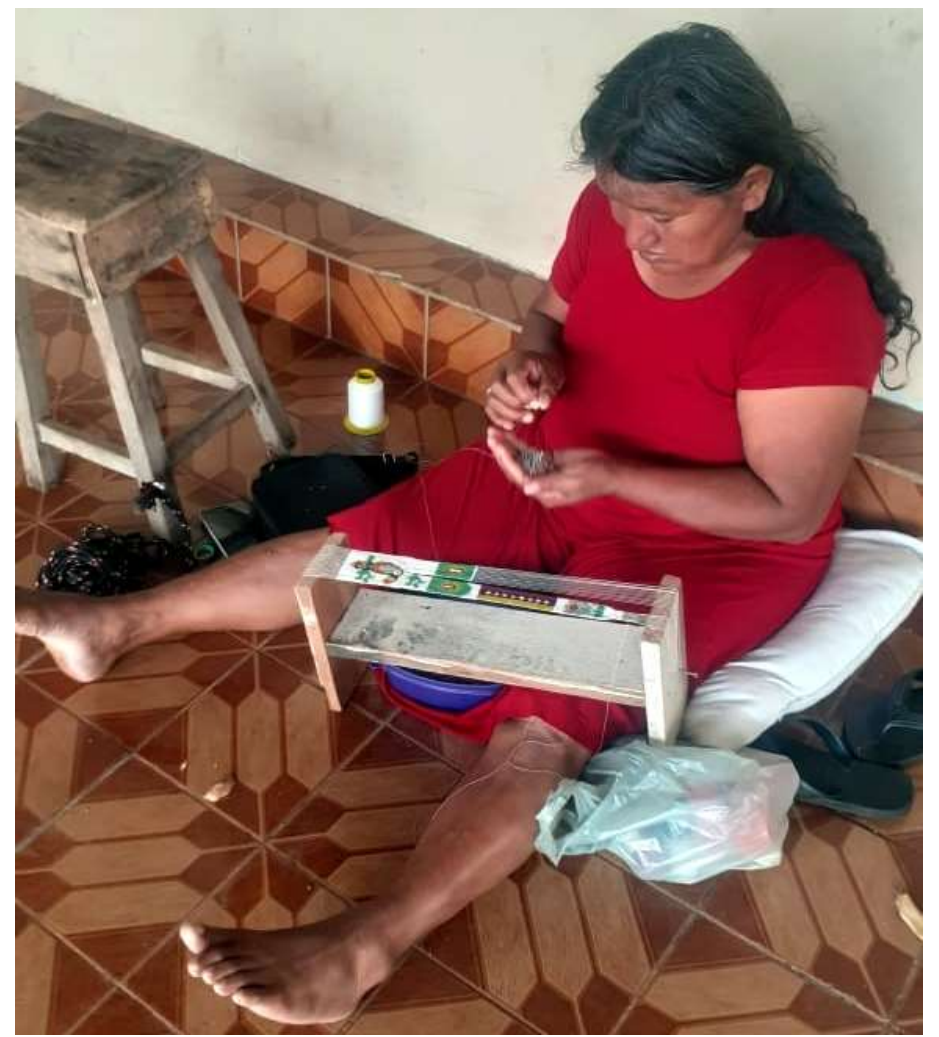

Fonte: Fotografia enviada aos autores. Rodolfo Rivero (Setembro de 2020).

No momento, o artesanato se constitui para Florencia tanto enquanto uma expectativa de autonomia para o futuro, como um motivo de gosto e orgulho: "Esse é meu trabalho, eu gosto desse trabalho, gosto de fazer". Junto com isso, surgem algumas preocupações, como, por exemplo, qual preço devem cobrar pelas peças. Por isso, não poucas vezes, as fotografias das peças que nos mostram são acompanhadas da seguinte pergunta: "como podemos vender aqui, qual o preço?". A fabricação de artesanato, hoje possibilitada, em parte, pela atuação da Associação que compra o material para os Warao e de outros agentes 
solidários, além de constituir-se como um horizonte de futuro baseado na autonomia, ao mesmo tempo em que expressa transformações na cultura warao, possibilita seu fortalecimento preenchendo o território brasileiro de novos significados enraizados na sua cosmologia e na sua história. Alguns dos animais que Florencia desenha em seu tear são correspondentes aos pontos cardeais da cosmologia warao, como as borboletas e as araras, além de outros símbolos nacionais, como quando faz pulseiras com a bandeira da Venezuela e o nome do país. Com o tempo e a permanência no Brasil, as imagens, que habilidosamente tece com pedrinhas em um tear, se modificam a partir das novas vivências. Não é raro, por exemplo, que nos mostre uma pulseira com a bandeira do Brasil, ou com as bandeiras dos dois países juntas, demonstrando as transformações que ocorrem a partir das novas interações que estabelece e os laços que busca consolidar com os grupos e pessoas que conhece em suas viagens ${ }^{58}$. É possível que, no decorrer de sua permanência no país, incorpore mais imagens brasileiras ao seu artesanato, como símbolos nacionais, ou animais da rica fauna do Pantanal.

\section{Considerações finais}

A história de Florencia e Rodolfo, apesar de suas particularidades, exemplifica os dois principais aspectos do contexto migratório e de mobilidade dos warao no Brasil. Primeiro, as dificuldades inerentes a um contexto estranho e até mesmo hostil, em que sequer o idioma lhes é familiar. Uma situação histórica que chama a atenção para os diversos tipos de violência sob os quais estão sujeitos como migrantes e como indígenas (ROSA, 2020). Segundo, mas não menos importante, demonstra o potencial criativo e (re)inventivo das culturas e práticas sociais - neste caso dos coletivos warao, que num território desconhecido sobrevivem reproduzindo-se e adaptando-se de acordo com as diversas relações que tecem ao longo do caminho.

As múltiplas formas de agência que a família de Florencia e Rodolfo estabeleceram e ainda estabelecem diante do contexto migratório chamam a atenção ao se configurarem principalmente por meio de um entrelaçado social, costurado de maneira similar ao trabalho que as artesãs warao realizam com a palma de oji. Com criollos, através das estratégias e interlocuções que conseguiram criar no intuito de - mesmo sem contas bancárias próprias - enviar dinheiro para os parentes que ficaram na Venezuela. Com a Associação que atualmente os concede uma casa para morarem até dezembro, e também, de modo mais geral, através da sua ampla rede de parentesco que os permite ir e vir e buscar materiais, mas sobretudo, existir, se redefinir e se fortalecer enquanto grupo étnico com a ajuda, notadamente, da comunicação via redes sociais.

A preocupação da formação de novos laços de solidariedade, de apoio e amizade é entendida como uma prioridade para Florencia, que

\footnotetext{
58 Por exemplo, em setembro de 2020, Florencia fabricou uma pulseira para cada "amigo" (com seu respectivo cônjuge) conhecido no Brasil e particularmente em Porto Alegre. 
não hesita em deixar presentes feitos com as próprias mãos para seus maraisa (amigos íntimos) e/ou aliados estratégicos: assim, na sua partida da cidade de Porto Alegre, onde estabelecemos as bases para nossa relação, fomos presenteados com belos colares da artesã warao. Ela adaptou sua maestria com a palma de oji - material de qualidade muito superior para a confecção destas peças, mas distante da realidade gaúcha - para a palha de milho retorcida e decorada com sementes, ainda que novas no seu ofício, como lágrimas de nossa senhora e pau-brasil. Um improviso do momento ,que exemplificou o potencial da reelaboração das práticas sociais, econômicas e culturais das mulheres warao diante do contexto da migração e do coronavírus.

Ao longo do convívio e através do fortalecimento do vínculo que estabelecemos - tanto como pesquisadores quanto como maraisa -, os diferentes elementos apresentados nesse texto foram surgindo e se articulando. Sendo assim, essa relação foi imprescindível para entender, através das dificuldades e necessidades, as preocupações dos Warao em jogo no contexto. Ao participar efetivamente desses problemas cotidianos - mesmo à distância -, os elementos relevantes para essas famílias se destacaram com mais facilidade, surgindo das demandas que nos eram apresentadas. Dessa maneira, foram se encontrando os pontos de articulação entre saúde, cosmologia, comida e trabalho na figura do hebu que sempre se soma ou explica: a doença, a fome e a dificuldade.

Esse trabalho foi realizado a partir de uma etnografia com apenas uma família extensa warao. Longe de querer generalizar sua experiência, acreditamos, porém, que sua trajetória fornece algumas pistas para entendermos as tramas das relações entre os Warao e a sociedade brasileira, incluindo as instituições estatais e entidades independentes. Se, por um lado, estas migrações devem ser consideradas como únicas, não só por acontecerem pela primeira vez pelos Warao do Delta do Orinoco da Venezuela para o Brasil, mas também por estarem atravessadas, neste momento, por uma pandemia de proporções globais, por outro, apesar das suas especificidades, o caso da família de Florencia e Rodolfo parece se assemelhar ao de muitas famílias warao que se deslocam para o Brasil, constituindo-se, assim, como um exemplo das situações atravessadas por esses coletivos e das estratégias que eles desenvolvem para permanecerem fortalecidos.

Das emergências encontradas no cotidiano de Florencia, como problemas de pressão, o frango roubado, a sua dupla jornada de trabalho (o que ela não pode abrir mão em função da falta de trabalho digno para seu marido), emergem as categorias e os temas relevantes à pesquisa. Nesse sentido, voltamos a ressaltar a importância que o engajamento cotidiano tem na elaboração de uma pesquisa que leve em consideração os interesses e necessidades dos próprios interlocutores. Na tentativa de subverter a fórmula da antropologia colonial em que categorias abstratas são o foco dos estudos de pesquisadores que costumam desconsiderar as intencionalidades e o protagonismo dos seus interlocutores no tecer da ação social, e invisibilizar, assim, problemas muito reais e concretos que existem naquela situação etnográfica (PACHECO DE OLIVEIRA, 2006), optamos por usar nosso trabalho inicial para entender o que naquele 
momento era relevante ser pesquisado e desvelado. Essa proposta não é novidade. Entre outras, Alcida Ramos (2012, p.491) já afirmou antes que "não importa qual seja a preferência teórica dos antropólogos, eles nunca devem abrir mão de seu papel como atores políticos responsáveis."

No Brasil, os Warao empenham-se a todo momento, para fugir da invisibilidade na qual tanto o Estado brasileiro quanto a sociedade civil tentam lhes encarcerar. A batalha contra a invisibilização se faz, em parte, no front da memória - que, longe de ser entendida como um saco de antiguidades, deve ser lida como um ponto de partida para a (re)construção do futuro. As transformações sociais se articulam com a memória, que ao tornar-se coletiva, consolida as identidades warao em espaços que se (re)territorializam, carregando, assim, significados warao para os novos territórios caminhados e habitados. Na mesma medida em que os hebu podem aparecer nos rios brasileiros, nas águas do ralo ou no chuveiro de uma casa em Cuiabá, trazendo o universo warao para dentro deste novo território possibilitando projetar um futuro, o suco de oji constitui-se como uma referência capaz de atar o caño Manamo ao rio Guaíba e o presente ao passado.

Em 20 de junho de 2020, na ocasião do dia mundial dos refugiados, os familiares de Rodolfo - inclusive seu irmão - celebraram em Manaus o primeiro aniversário da chegada do grupo no Brasil. Neste dia, os Warao organizaram o ritual do najanamu celebrado anualmente em homenagem aos ancestrais Kanobotuma. Tradicionalmente, os Warao se reúnem por três ou quatro dias para brindar os seus antepassados pela colheita de aru. Os espíritos Kanobotuma, ou "avós espirituais", são os antepassados dos Warao que habitam o mundo celestial. Sábios que exigem que vivam um restrito código moral e ético. A primeira colheita de $a r u$, portanto, é dedicada como alimento sagrado aos Kanobotuma, pedindo que garantam a sobrevivência dos Warao em um mundo difícil. Dessa forma, seguem amparados pelos seus guias espirituais, que aconselham como superar a fome, as doenças, e a morte prematura das crianças. A celebração do aru representa assim um vínculo transcendental entre o homem, a natureza, e o mundo eterno. Na realização do ritual colocamse duas representações de hebu no centro da roda (um masculino, e um feminino), e o grupo começa a dançar em torno, com as maracas sendo tocadas pelo wisidatu, que coordena toda a celebração, e sua esposa dança perto das representações ${ }^{59}$. Em Manaus, o grupo warao estava reunido em um ginásio trajando roupas coloridas e carregando chocalhos improvisados com garrafa PET, e, felizes, realizavam de forma pulsante a sua festa. Na ausência de um wisidatu e sua esposa, cada pessoa homens e mulheres warao e até mesmo funcionários do centro de acolhimento - tinha sua vez de dançar perto das representações de hebu. Todos eram celebrados em voz alta ao dançarem aos risos de alegria. 0 najanamu, agora celebrado também no Brasil, embora sem colheita prévia de aru, consolida o grupo e (re)estabelece entre seus integrantes uma linguagem comum que lhes lembra quem são e de onde vêm.

\footnotetext{
${ }^{59}$ Retiramos essas informações do documentário Hijas de la Luna, que Florencia e Rodolfo nos convidaram a assistir para conhecer "sua cultura". Fonte: <https://vimeo.com/430717290?ref=fb-share.> Acesso em: 19/09/2020.

MARÉCHAL, Clémentine; VELHO, Augusto Leal de Britto; RODRIGUES, Milena Weber; BUENO, Pietro. Transformações sociais e (re)territorialização Warao no Brasil: a trajetória de uma família frente à pandemia de covid-19. Espaço Ameríndio, Porto Alegre, v. 14, n. 2, p. 46-87, jul./dez. 2020.
} 
Espaço Ameríndio

Rodolfo nos explica: "os ancestrais sabem mais que nós. Eles vêm nos avisar. Por isso te digo que é algo muito sagrado para nós". O najanamu se reinventa num Brasil que pouco a pouco se pinta com as cores, os cânticos e as danças warao. O ritual ganha força se estendendo, como os caranguejos de Brasília, até o grupo familiar de Florencia em Cuiabá e ressoa em Porto Alegre nas mensagens de vídeo e voz de nossos celulares. Tecendo sua história nas estradas e nas cidades brasileiras, os Warao, ao mesmo tempo em que transformam suas práticas sociais, rituais, econômicas e culturais, mudam o Brasil através do seu protagonismo e da sua determinação. Levantam, assim, novos desafios para o indigenismo brasileiro e para pesquisadores comprometidos com as lutas dos povos indígenas.

Imagem 4 - Ritual do Najanamu realizado em 20 de junho na ocasião do dia do refugiado em Manaus (AM).

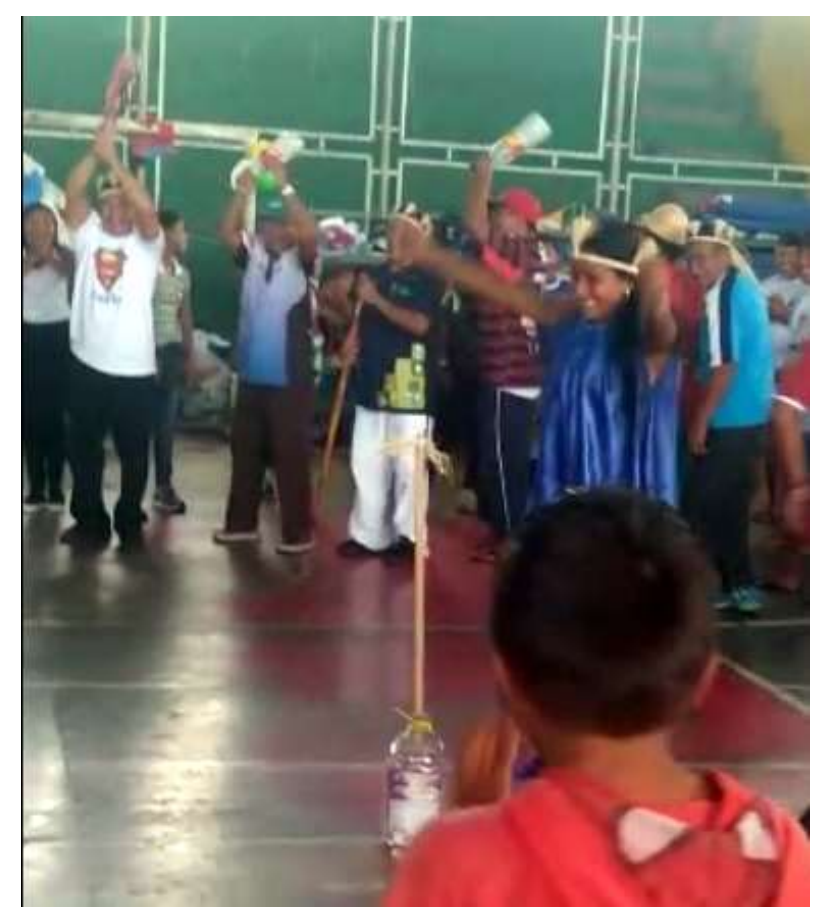

Fonte: Fotografia enviada aos autores. Autor desconhecido. 
Espaço Ameríndio

\section{Referências bibliográficas}

ALBERT, Bruce. "Situação etnográfica" e movimentos étnicos. Notas sobre o trabalho de campo pós-malinowskiano. Campos, Curitiba, v.15, nº1, p. 129-143, 2014.

AMODIO, Emanuele; RIVAS, Yelitza; DOX, Clever. Las pautas de crianza del pueblo warao de Venezuela. Caracas: Asha Ediciones, 2006.

AYALA LAFÉE-WILBERT, Cecilia; WILBERT, Werner. La mujer Warao: de recoletora deltana a recoletora urbana. Caracas: Fundación La Salle de Ciencias Naturales, Instituto Caribe de Antropología y Sociología, 2008.

BARBOSA DA SILVA, Alexandra. Mais além da "aldeia": território e redes sociais entre os Guarani de Mato Grosso do Sul. 2007. 256 f. Tese (Doutorado em Antropologia Social) - Rio de Janeiro: UFRJ/ MN/ PPGAS, 2007.

BARTH, Fredrik. Grupos étnicos e suas fronteiras. In: POUTIGNAT, Philippe; STREIFF-FENART, Jocelyne. Teorias da etnicidade. São Paulo: UNESP, 2011.

BELLO, Luis Jesus. Derechos de los pueblos indígenas en el nuevo ordenamiento jurídico venezolano. Caracas: IWGIA, 2005.

BRIGGS, Charles. Poéticas de Vida en Espacios de Muerte: Género, poder y Estado en la cotidianeidad Warao. Quito: Abya-Yala, 2008.

BRIGGS, Charles; MANTINI-BRIGGS, Clara. Tell Me Why My Children Died: Rabies, Indigenous Knowledge, and Communicative Justice. Durham: Duke University Press, 2016.

CARNEIRO, Henrique. Comida e sociedade: uma história da alimentação. Rio de Janeiro: Editora Campus, 2003.

CORONIL, Fernando. Más allá del occidentalismo: hacia categorías geohistóricas noimperiales. Casa de las Américas, La Habana, v. 39, n. 214, p. 21-49, 1999.

DOUGLAS, Mary. Pureza e Perigo: ensaio sobre a noção de poluição e tabu. Rio de Janeiro: Edições 70, 1991.

FASSIN, Didier. Compaixão e repressão: A economia moral das Políticas de Imigração na França. Ponto Urbe, $n^{\circ}$ 15, p. 1-26, 2014.

FASSIN, Didier. Quand le corps fait loi: La raison humanitaire dans les procédures de régularisation des étrangers. Sciences sociales et santé, vol. 19, n 4, p. 5-34, 2001.

GALLOIS, Dominique. Porque valorizar os patrimônios culturais indígenas. Cienc. Cult. São Paulo, vol. 60, n 4, p. 34-36, Oct. 2008.

GARCÍA-CASTRO, Álvaro. Los Warao en Brasil son refugiados, no inmigrantes. Cuestiones etnológicas y etnohistóricas. Périplos: Revista De Estudos Sobre 
Espaço Ameríndio

Migrações, v. 2, n. 2, p. 32-55, Dez. 2018.

GARCÍA-CASTRO, Álvaro. Migración de indígenas Warao para formar barrios marginales en la periferia de ciudades de Guayana, Venezuela. In: REPRESA PERÉZ, F. (org.) De Quito a Burgos: migraciones y ciudadanía. Burgos: Gran Vía, 2006.

GARCÍA-CASTRO, Álvaro. Mendicidad indígena: los Warao urbanos. Boletín Antropológico, Mérida, n 48, p. 79-90, 2000.

GARCÍA-CASTRO, Álvaro; HEINEN, Dieter. Planificando el desastre ecológico: impacto del cierre del caño Manamo para las comunidades indígenas y criollas del Delta Occidental (Delta del Orinoco, Venezuela). Antropológica, n 91, Caracas, p. 31-56, 1999.

GASSÓN, Rafael; HEINEN, Dieter. ¿Existe un Warao genérico?: cuestiones clave en la etnografía y la ecología histórica del Delta del Orinoco y el territorio Warao-LokonoParagoto. Tipití: Journal of the Society for the Anthropology of Lowland South America, vol. 10, $\mathrm{n}^{\circ}$ 1, p. 37-67, 2012.

GOW, Peter. Of mixed blood. Kinship and history in Peruvian Amazon. Oxford: Claredon Press, 1991.

GROISMAN, Alberto. O Santo Daime e a Nova Peregrinação. Estudos Leopoldenses, v. 32, p. 111-119, 1996.

HIJAS de la Luna. Direção de Andrés Meyes. S.I.: Ocala Producciones, 2006. (55 min.), color. Baseado no livro Hijas de la Luna de Cecilia Ayala Lafeé y Werner Wilbert..

HILL, Jonathan. Introduction. In: HILL, Jonathan (Ed.) Rethinking History and Myth. Indigenous South American Perspectives on the Past. University of Illinois Press, 1988.

MARÉCHAL, Clémentine. Sonhar, Curar, Lutar: Colonialidade, Xamanismo e Cosmopolítica Kaingang no Rio Grande do Sul. Editora Appris: Curitiba, 2019.

MARX, Karl. O Capital: critica da economia política I. São Paulo: Boitempo, 2013.

MCCALLUM, Cecilia. Alteridade e sociabilidade kaxinauá: perspectivas de uma antropologia da vida diária. Revista Brasileira de Ciências Sociais, São Paulo, v. 13, n. 38, Oct. 1998.

MEILLASSOUX, Claude. Femmes, greniers et capitaux. Paris: Maspero, 1975.

MOREIRA, Elaine; TORELLY, Marcelo [coordenadores]. Soluções duradouras para indígenas migrantes e refugiados no contexto do fluxo venezuelano no Brasil. Brasília: Organização Internacional para as Migrações (OIM), 2020.

MINTZ, Sidney W. Sweetness and Power: The Place of Sugar in Modern History. New York: Penguin Books, 1986.

MOUTINHO, Pedro. Parecer técnico No 10/2017 - SP/MANAUS/SEAP. Ministério 
Espaço Ameríndio

Público Federal (MPF), 2017.

OLIVEIRA, Assis da Costa. Direitos Humanos dos Indígenas Crianças: perspectivas para a construção da Doutrina da Proteção Plural. 2012. 245 f. Dissertação (Mestrado em Direito) - UFPA, Belém, PA, 2012.

PACHECO DE OLIVEIRA, João. Hacia uma antropologia del indigensimo. Lima: Centro Amazónico de Antropología y Aplicacón Práctica, 2006.

PACHECO DE OLIVEIRA, João. Uma etnologia dos "índios misturados"? Situação colonial, territorialização e fluxos culturais. Mana, Rio de Janeiro, v. 4, n. 1, p. 47-77, 1998.

PACHECO DE OLIVEIRA, João. O nascimento do Brasil e outros ensaios: "pacificação", regime tutelar e formação de alteridades. Rio de Janeiro: Contra Capa, 2016.

QUIJANO, Aníbal. "Colonialidade do poder, eurocentrismo e América Latina". In: LANDER, Edgardo (org.). A colonialidade do saber: eurocentrismo e ciências sociais. Perspectivas latino-americanas. Buenos Aires: CLACSO, 2005. p. 117-142.

QUIJANO, Aníbal. La economía popular y sus caminos en América Latina. LIMA: Mosca Azul, 1998.

QUINTERO, Pablo. Pueblos indígenas, Estado y democracia en Venezuela. Nosotros los Otros, Buenos Aires, n.7, p. 36-40, 2007.

QUINTERO, Pablo. Notas sobre la teoría de la colonialidad del poder y la estructuración de la sociedad en América Latina. In: QUIJANO, Aníbal (org) Des/Colonialidad y Bien Vivir: Un debate en América Latina. Lima: Universidad Ricardo Palma, 2014, p. 193216.

QUINTERO, Pablo. Peuples autochtones et politiques indigénistes au Venezuela (19992018). In: GARZÓN, Olga; SALLERIN, Mathilde; URIBE CARREÑO, Enrique (orgs.). Venezuela, la révolution bolivarienne, 20 ans après. Paris: L'Harmattan, 2020, p. 159167.

RAMOS, Luciana; BOTELHO, Emília; TARRAGÓ, Eduardo. Parecer Técnico No 208/2017/SEAP/6 CCR/PFDC. Ministério Público Federal (MPF), 2017.

RAMOS, Alcida Rita. The Politics of perspectivism, Annual Review of Anthropology, v. 41, p. 481-494, 2012.

RIBEIRO, Darcy. O povo brasileiro: a formação e o sentido do Brasil. São Paulo: Companhia das Letras, 1995.

ROSA, Marlise. A mobilidade Warao no Brasil e os modos de gestão de uma população em trânsito: reflexões a partir das experiências de Manaus-AM e de BelémPA. 2020. 311 f. Tese (Doutorado em Antropologia Social) - Museu Nacional, UFRJ, Rio de Janeiro, RJ, 2020. 
SAYAD, Abdelmalek. A imigração ou os paradoxos da alteridade. São Paulo: Edusp, 1998.

WILBERT, Johannes. Mystic endowment: religious ethnography of the Warao indians. Cambridge: Center for the Study of World Religions, 1993.

Recebido em: 09/10/2020 * Aprovado em: 29/11/2020 * Publicado em: 16/12/2020 